\title{
Firms, Contracts, and Trade Structure
}

\section{Citation}

Antras, Pol. 2003. Firms, contracts, and trade structure. Quarterly Journal of Economics 118(4): $1375-1418$.

\section{Published Version}

http://dx.doi.org/10.1162/003355303322552829

\section{Permanent link}

http://nrs.harvard.edu/urn-3:HUL.InstRepos:3196328

\section{Terms of Use}

This article was downloaded from Harvard University's DASH repository, and is made available under the terms and conditions applicable to Other Posted Material, as set forth at http:// nrs.harvard.edu/urn-3:HUL.InstRepos:dash.current.terms-of-use\#LAA

\section{Share Your Story}

The Harvard community has made this article openly available.

Please share how this access benefits you. Submit a story.

Accessibility 


\title{
FIRMS, CONTRACTS, AND TRADE STRUCTURE*
}

\author{
Pol Antràs
}

\begin{abstract}
Roughly one-third of world trade is intrafirm trade. This paper starts by unveiling two systematic patterns in the volume of intrafirm trade. In a panel of industries, the share of intrafirm imports in total U. S. imports is significantly higher, the higher the capital intensity of the exporting industry. In a cross section of countries the share of intrafirm imports in total U. S. imports is significantly higher, the higher the capital-labor ratio of the exporting country. I then show that these patterns can be rationalized in a theoretical framework that combines a Grossman-Hart-Moore view of the firm with a Helpman-Krugman view of international trade. In particular, I develop an incomplete-contracting, property-rights model of the boundaries of the firm, which I then incorporate into a standard trade model with imperfect competition and product differentiation. The model pins down the boundaries of multinational firms as well as the international location of production, and it is shown to predict the patterns of intrafirm trade identified above. Econometric evidence reveals that the model is consistent with other qualitative and quantitative features of the data.
\end{abstract}

\section{INTRODUCTION}

Roughly one-third of world trade is intrafirm trade. In 1994, 42.7 percent of the total volume of U. S. imports of goods took place within the boundaries of multinational firms, with the share being 36.3 percent for U. S. exports of goods [Zeile 1997]. Not only is intrafirm trade a large fraction of world trade, but it also shows some distinctive patterns. Relative to the total volume of trade, intrafirm trade (i) is heavily concentrated in capitalintensive industries and (ii) flows mostly between capital-abundant countries. Figure I provides a striking illustration of the first fact. In a cross section of 23 manufacturing industries, the share of intrafirm imports in total U. S. imports is significantly higher, the higher the capital intensity of the exporting industry. Firms

* I am grateful to Daron Acemoglu, George-Marios Angeletos, Gene Grossman, and Jaume Ventura for invaluable guidance, and to Manuel Amador, Lucia Breierova, Francesco Caselli, Fritz Foley, Gino Gancia, Andrew Hertzberg, Elhanan Helpman, Bengt Holmström, Ben Jones, Oscar Landerretche, Alexis León, Gerard Padró-i-Miquel, Thomas Philippon, Diego Puga, Jeremy Stein, Joachim Voth, two anonymous referees, and the editor (Edward Glaeser) for very helpful comments. I have also benefited from suggestions by seminar participants at the University of California at Berkeley, Graduate School of Business of the University of Chicago, Columbia University, Harvard University, the London School of Economics, the Massachusetts Institute of Technology, the National Bureau of Economic Research, Northwestern University, New York University, Princeton University, the University of California at San Diego, Stanford University, and Yale University. Financial support from the Bank of Spain is gratefully acknowledged. All remaining errors are my own.

() 2003 by the President and Fellows of Harvard College and the Massachusetts Institute of Technology.

The Quarterly Journal of Economics, November 2003 


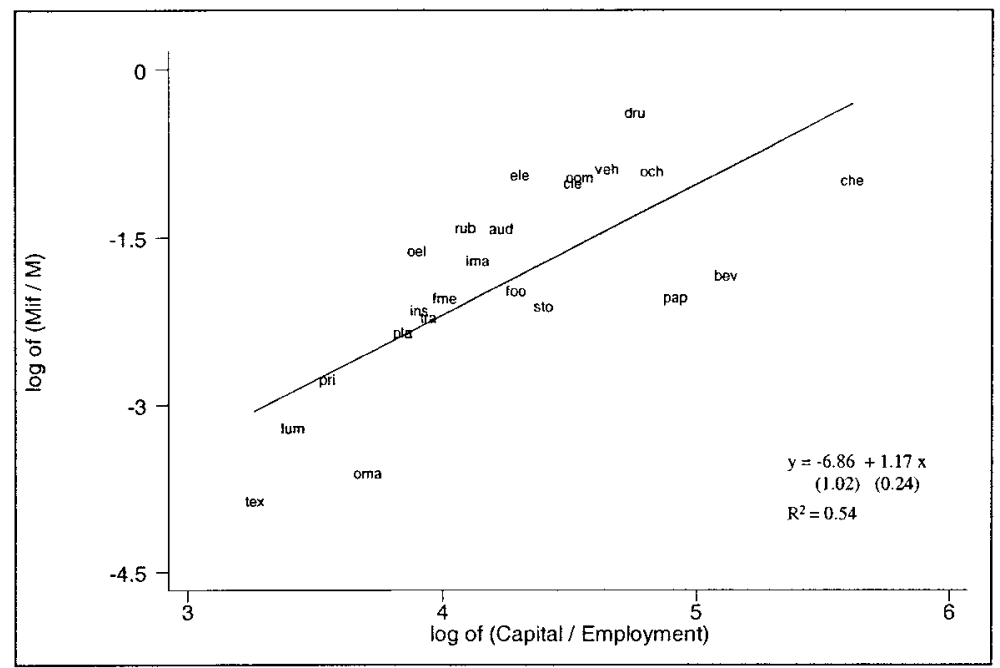

FIGURE I

Share of Intrafirm U. S. Imports and Relative Factor Intensities

The $Y$-axis corresponds to the logarithm of the share of intrafirm imports in total U. S. imports for 23 manufacturing industries averaged over four years: $1987,1989,1992,1994$. The $X$-axis measures the average log of that industry's ratio of capital stock to total employment, using U. S. data. See Appendix 4 for industry codes and Appendix 3 for data sources.

in the United States tend to import capital-intensive goods, such as chemical products, within the boundaries of their firms, while they tend to import labor-intensive goods, such as textile products, from unaffiliated parties. Figure II unveils a second strong pattern in the share of intrafirm imports. In a cross section of 28 countries, the share of intrafirm imports in total U. S. imports is significantly higher, the higher the capital-labor ratio of the exporting country. U. S. imports from capital-abundant countries, such as Switzerland, tend to take place between affiliated units of multinational firms, while U. S. imports from capital-scarce countries, such as Egypt, occur mostly at arm's length. This second fact indicates that the well-known predominance of North-North trade in total world trade is even more pronounced within the intrafirm component of trade. ${ }^{1}$

1. This is consistent with comparisons based on foreign direct investment (FDI) data. In the year 2000 more than 85 percent of FDI flows occurred between developed countries [UNCTAD 2001], while the share of North-North trade in total world trade was roughly 70 percent [World Trade Organization 2001]. 


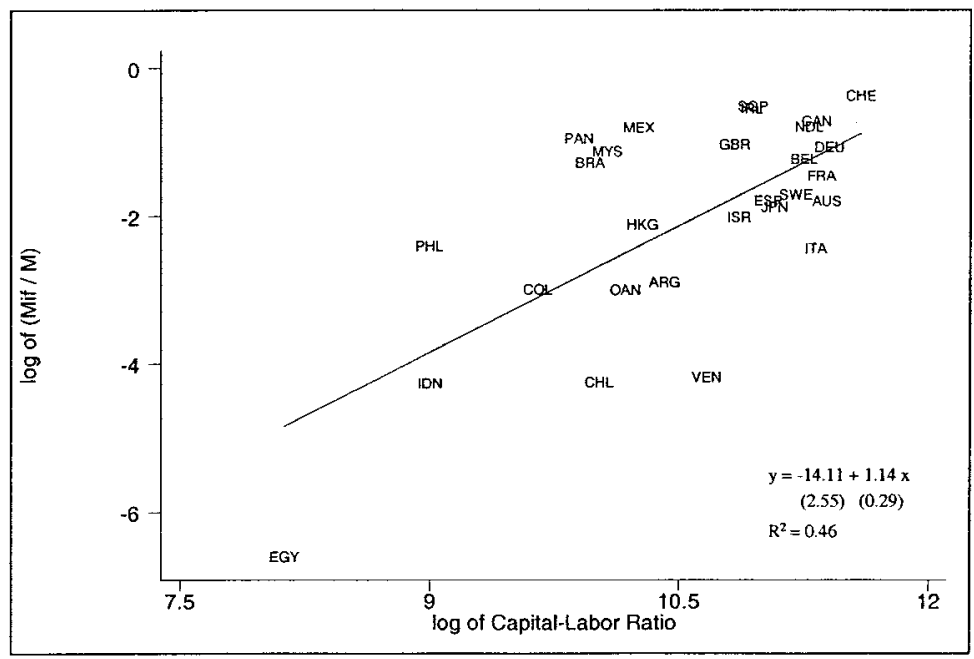

FIGURE II

Share of Intrafirm U. S. Imports and Relative Factor Endowments

The $Y$-axis corresponds to the logarithm of the share of intrafirm imports in total U. S. imports for 28 exporting countries in 1992. The $X$-axis measures the log of the exporting country's physical capital stock divided by its total number of workers. See Appendix 5 for country codes and Appendix 3 for details on data sources.

Why are capital-intensive goods transacted within the boundaries of multinational firms, while labor-intensive goods are traded at arm's length? ${ }^{2}$ Indeed, in a hypothetical world in which firm boundaries had no bearing on the pattern of international trade, one would expect only random differences between the behavior of the volume of intrafirm trade and that of the total volume of trade. In particular, the share of intrafirm trade in total trade would not be expected to correlate significantly with any of the classical determinants of international trade, including capital intensity. To answer this question, I build on the theory of the firm initially exposited in Coase [1937] and later developed by Williamson [1985] and Grossman and Hart [1986], by which activities take place wherever transaction costs are minimized. In particular, I develop a property-rights model of the boundaries of the firm in which, in equilibrium, transaction costs of using the

2. At this point, a natural question is whether capital intensity and capital abundance are truly the crucial factors behind the correlations in Figures I and II. Section IV will present econometric evidence indicating that these patterns are not driven by omitted factors. 
market are increasing in the capital intensity of the imported good. To explain the cross-country pattern in Figure II, I then embed this partial-equilibrium framework in a general-equilibrium, factor-proportions model of international trade, with imperfect competition and product differentiation, along the lines of Helpman and Krugman [1985]. Capital-intensive goods are transacted within firm boundaries, while labor-intensive goods are traded at arm's length. The model pins down the boundaries of multinational firms as well as the international location of production. Bilateral trade flows between any two countries are uniquely determined, with capital-abundant countries capturing relatively large shares of a country's imports of capital-intensive goods. The interaction of transaction-cost minimization and comparative advantage is shown to naturally give rise to the relationship between intrafirm trade and relative factor endowments in Figure II. ${ }^{3}$

In drawing firm boundaries, I build on the seminal work of Grossman and Hart [1986]. I consider a world of incomplete contracts in which final-good producers need to obtain specialized intermediate inputs from their suppliers. Production of these intermediate inputs requires a combination of noncontractible and relationship-specific investments in capital and labor. Following the property-rights approach of Grossman and Hart, ownership of their suppliers entitles final-good producers to some residual rights of control, thus improving their ex post bargaining position, but reducing the suppliers' ex ante incentives to make relationship-specific investments. When all investments in production are incurred by suppliers, efficiency dictates that finalgood producers always give up these residual rights of control and engage in arm's length transactions.

To explain the higher propensity to integrate in capitalintensive industries, I extend the framework of Grossman and Hart [1986] by allowing the transferability of capital investment decisions. In particular, I show that in situations in which the bargaining power of suppliers is low, giving up these residual rights of control may not suffice to induce suppliers to undertake adequate levels of investment. In such situations, final-good producers will find it optimal to alleviate the holdup problem faced

3. This second part of the argument is based on the premise that capitalabundant countries tend to export mostly capital-intensive commodities. Romalis [2002] has recently shown that the empirical evidence is indeed consistent with factor proportions being a key determinant of the structure of international trade. 
by suppliers by contributing to their relationship-specific investments in capital. Investment-sharing reduces the holdup faced by suppliers, but naturally increases the exposure of final-good producers to opportunistic behavior, with the exposure being an increasing function of the contribution to investment costs. If capital cost sharing is large enough, as it will naturally be the case in capital-intensive processes, ex ante efficiency is shown to command that residual rights of control, and thus ownership, be assigned to the final-good producer, thus giving rise to vertical integration. In general, the attractiveness of vertical integration is shown to be increasing in the capital intensity of intermediate input production. ${ }^{4}$

The argument is based on the premise that investments related to the labor input are harder to share than investments in physical capital. This may be the result of suppliers having superior local knowledge in hiring workers, or it may be explained by the fact that managing workers requires a physical presence in the production plant. Business practices indeed suggest that cost sharing is more prevalent in capital investments. Dunning [1993, pp. 455-456] describes several cost-sharing practices of multinational firms in their relations with independent subcontractors. Among others, these include provision of used machinery and specialized tools and equipment, prefinancing of machinery and tools, and procurement assistance in obtaining capital equipment. There is no reference to cost sharing in labor costs, other than in labor training. Milgrom and Roberts [1993] discuss the particular example of General Motors, which pays for firm- and product-specific capital equipment needed by their suppliers, even when this equipment is located in the suppliers' facilities. Similarly, in his review article on Japanese firms, Aoki [1990, p. $25]$ describes the close connections between manufacturers and their suppliers but writes that "suppliers have considerable autonomy in other respects, for example in personnel administration." Even within firm boundaries, cost sharing seems to mostly take place when capital investments are involved. In particular, Table I indicates that British affiliates of U. S.-based multina-

4. Although in this paper I show that a Grossman-Hart-Moore view of the firm is consistent with the facts in Figures I and II, neither my theoretical model nor the available empirical evidence is rich enough to test this view of the firm against alternative ones. This would be a major undertaking on its own. See Baker and Hubbard [2002] and Whinston [2002] for more formal treatments of these issues. 
TABLE I

Decision-Making in U. S. Based Multinationals

\begin{tabular}{lllr}
\hline \hline \multicolumn{2}{c}{$\%$ of British affiliates in which parent influence on decision is strong or decisive } \\
\hline Financial decisions & 51 & Employment/personnel decisions & Union recognition \\
Setting of financial targets & 20 & Collective bargaining & 4 \\
Preparation of yearly budget & 44 & Wage increases & 1 \\
Acquisition of funds for working capital & 33 & Numbers employed & 13 \\
Choice of capital investment projects & 46 & Layoffs/redundancies & 10 \\
Financing of investment projects & 68 & Hiring of workers & 10 \\
Target rate of return on investment & 30 & Recruitment of executives & 16 \\
Sale of fixed assets & 82 & Recruitment of senior & 13 \\
Dividend policy & 82 & managers & \\
Royalty payments to parent company & \multicolumn{3}{c}{} \\
\hline \hline
\end{tabular}

Source. Dunning [1993, p. 227]. Originally from Young, Hood, and Hamill [1985].

tionals tend to have much more independence in their employment decisions (e.g., in hiring of workers) than in their financial decisions (e.g., in their choice of capital investment projects).

This paper is related to previous theoretical studies of the multinational firm in general-equilibrium models of international trade. This literature has developed models rationalizing the emergence of multinational firms in the presence of international factor-price differentials (e.g., Helpman [1984]), whenever transport costs are high, and whenever firm-specific economies of scale are high relative to plant-specific economies of scale (e.g., Markusen [1984] and Brainard [1997]). These different approaches to the multinational firm share a common failure to properly model the crucial issue of internalization. These models can explain why a domestic firm might have an incentive to undertake part of its production process abroad, but they fail to explain why this foreign production will occur within firm boundaries rather than through arm's length subcontracting or licensing. In the same way that a theory of the firm based purely on technological considerations does not constitute a satisfactory theory of the firm (cf. Tirole [1988] and Hart [1995]), a theory of the multinational firm based solely on economies of scale and transport costs cannot be satisfactory either. As described above, I will instead set forth a purely organizational, property-rights model of the multinational firm. My model will make no distinction between firm-specific and plant-specific economies of scale. Furthermore, trade will be costless, and factor prices will not differ across countries. Yet multinationals will emerge in equilib- 
rium, and their implied intrafirm trade flows will match the strong patterns identified above. ${ }^{5}$

The rest of the paper is organized as follows. Section II describes the closed-economy version of the model and studies the role of factor intensity in determining the equilibrium mode of organization. Section III describes the multicountry version of the model and discusses the international location of production as well as the implied patterns of intrafirm trade. Section IV presents econometric evidence supporting the view that both capital intensity and capital abundance are significant factors in explaining the volume of U. S. intrafirm imports. Section V concludes. The proofs of the main results are relegated to Appendixes 1 and 2.

\section{The Closed-Economy Model: Ownership AND CAPITAL INTENSITY}

This section develops an incomplete-contracting, propertyrights model of the boundaries of the firm that rationalizes a higher motive of integration in capital-intensive sectors.

\section{II.A. Setup}

Consider a closed economy that employs two factors of production, capital and labor, to produce a continuum of varieties in two sectors, $Y$ and $Z$. Capital and labor are inelastically supplied and freely mobile across sectors. The economy is inhabited by a unit measure of identical consumers who view the varieties in each industry as differentiated. In particular, letting $y(i)$ and $z(i)$ be consumption of variety $i$ in sectors $Y$ and $Z$, preferences of the representative consumer are of the form,

$$
U=\left(\int_{0}^{n_{Y}} y(i)^{\alpha} d i\right)^{\mu / \alpha}\left(\int_{0}^{n_{Z}} z(i)^{\alpha} d i\right)^{(1-\mu) / \alpha},
$$

5. This paper is also related to previous attempts to model the internalization decision of multinational firms. Following the insights from the seminal work of Casson [1979], Rugman [1981], and others, this literature has constructed models studying the role of informational asymmetries and knowledge nonexcludability in determining the choice between direct investment and licensing (e.g., Ethier [1986] and Ethier and Markusen [1996]). This paper differs from this literature in stressing the importance of capital intensity and the allocation of residual rights in the internalization decision, and perhaps more importantly, in describing and testing the implications of such a decision for the pattern of intrafirm trade. My theoretical framework also shares some features with recent contributions to an emerging literature on general-equilibrium models of industry structure (e.g., McLaren [2000] and Grossman and Helpman [2002a, 2002b]). 
where $n_{Y}\left(n_{Z}\right)$ is the endogenously determined measure of varieties in industry $Y(Z)$. Consumers allocate a constant share $\mu \in$ $(0,1)$ of their spending in sector $Y$ and a share $1-\mu$ in sector $Z$. The elasticity of substitution between any two varieties in a given sector, $1 /(1-\alpha)$, is assumed to be greater than one.

Goods are also differentiated in the eyes of producers. In particular, each variety $y(i)$ requires a special and distinct intermediate input which I denote by $x_{Y}(i)$. Similarly, each variety $z(i)$ requires a distinct component $x_{Z}(i)$. The specialized intermediate input must be of high quality, otherwise the output of the final good is zero. If the input is of high quality, production of the final good requires no further costs, and $y(i)=x_{Y}(i), z(i)=x_{Z}(i)$.

Production of a high-quality intermediate input requires capital and labor. For simplicity, technology is assumed to be Cobb-Douglas:

$$
x_{k}(i)=\left(\frac{K_{x, k}(i)}{\beta_{k}}\right)^{\beta_{k}}\left(\frac{L_{x, k}(i)}{1-\beta_{k}}\right)^{1-\beta_{k}}, \quad k \in\{Y, Z\},
$$

where $K_{x, k}(i)$ and $L_{x, k}(i)$ denote the amount of capital and labor employed in production of variety $i$ in industry $k \in\{Y, Z\}$. I assume that industry $Y$ is more capital-intensive than industry $Z$; i.e., $1 \geq \beta_{Y}>\beta_{Z} \geq 0$. Low-quality intermediate inputs can be produced at a negligible cost in both sectors.

There are also fixed costs associated with the production of an intermediate input. To simplify matters, it is assumed that fixed costs in each industry have the same factor intensity as variable costs, so that the total cost functions are homothetic. In particular, fixed costs for each variety in industry $k \in\{Y, Z\}$ are $f r^{\beta_{k}} w^{1-\beta_{k}}$, where $r$ is the rental rate of capital and $w$ the wage rate.

There are two types of producers: final-good producers and suppliers of intermediate inputs. Before any investment is made, a final-good producer decides whether it wants to enter a given market, and if so, whether to obtain the component from a vertically integrated supplier or from a stand-alone supplier. An integrated supplier is just a division of the final-good producer and thus has no control rights over the amount of input produced. Figuratively, at any point in time the parent firm could selectively fire the manager of the supplying division and seize production. Conversely, a stand-alone supplier does indeed have these residual rights of control. In Hart and Moore's [1990] words, in such a case the final-good producer could only "fire" the entire 
supplying firm, including its production. Integrated and nonintegrated suppliers differ only in the residual rights they are entitled to, and in particular both have access to the same technology as specified in equation (2). ${ }^{6}$

As discussed in the Introduction, a premise of this paper is that investments in physical capital are easier to share than investments in labor input. To capture this idea, I assume that while the labor input is necessarily provided by the supplier, capital expenditures $r K_{x, k}(i)$ are instead transferable, in the sense that the final-good producer can decide whether to let the supplier incur this factor cost too, or rather rent the capital itself and hand it to the supplier at no charge. ${ }^{7}$ Irrespective of who bears their cost, the investments in capital and labor are chosen simultaneously and noncooperatively. ${ }^{8}$ Once a final-good producer and its supplier enter the market, they are locked into the relationship: the investments $r K_{x, k}(i)$ and $w L_{x, k}(i)$ are incurred upon entry and are useless outside the relationship. In Williamson's [1985] words, the initially competitive environment is fundamentally transformed into one of bilateral monopoly. Regardless of firm structure and the choice of cost sharing, fixed costs associated with production of the component are divided as follows: $f_{F} r^{\beta_{k}} w^{1-\beta_{k}}$ for the final-good producer and $f_{S} r^{\beta_{k}} w^{1-\beta_{k}}$ for the supplier, with $f_{F}+f_{S}=f .^{9}$

Free entry into each sector ensures zero expected profits for a potential entrant. To simplify the description of the industry equilibrium, I assume that upon entry the supplier makes a lump-sum transfer $T_{k}(i)$ to the final-good producer, which can vary by industry and variety. Ex ante, there are a large number of identical, potential suppliers for each variety in each industry, so that competition among these suppliers will make $T_{k}(i)$ adjust so as to make them break even. The final-good producer chooses

6. This is in contrast with the transaction-cost literature that usually assumes that integration leads to an exogenous increase in variable costs (e.g., Williamson [1985] and Grossman and Helpman [2002a]).

7. Alternatively, one could assume that labor costs are also transferable, but that their transfer leads to a significant fall in productivity. This fall in productivity could be explained, in an international context, by the inability of multinational firms to cope with idiosyncratic labor markets (cf., Caves [1996, p. 123]).

8. The assumption that the final-good producer decides between bearing all or none of the capital expenditures can be relaxed to a case of partial transferability (see Antràs [2003]).

9 . Henceforth, I associate a subscript $F$ with the final-good producer and a subscript $S$ with the supplier. 
the mode of organization so as to maximize its ex ante profits, which include the transfer.

The setting is one of incomplete contracts. It is assumed that an outside party cannot distinguish between a high-quality and a low-quality intermediate input. Hence, input suppliers and finalgood producers cannot sign enforceable contracts specifying the purchase of a certain type of intermediate input for a certain price. If they did, input suppliers would have an incentive to produce a low-quality input at the lower cost and still cash the same revenues. I take the existence of contract incompleteness as a fact of life, and will not complicate the model to relax the informational assumptions needed for this incompleteness to exist. ${ }^{10}$ It is equally assumed that no outside party can verify the amount of ex ante investments $r K_{x, k}(i)$ and $w L_{x, k}(i)$. If these were verifiable, then final-good producers and suppliers could contract on them, and the cost-reducing benefit of producing a low-quality input would disappear. For the same reason, it is assumed that the parties cannot write contracts contingent on sale revenues. Following Grossman and Hart [1986], the only contractibles ex ante are the allocation of residual rights and the ex ante transfer $T_{k}(i){ }^{11}$

If the supplier incurs all variable costs, the contract incompleteness gives rise to a standard holdup problem. The final-good producer will want to renegotiate the price after $x_{k}(i)$ has been produced, since at this point the intermediate input is useless outside the relationship. Foreseeing this renegotiation, the supplier will undertake suboptimal investments in both capital and labor. If the final-good producer shares capital expenditures with the supplier, the holdup problem becomes two-sided. Because the investment in capital is also specific to the pair, the final-good

10. From the work of Aghion, Dewatripont, and Rey [1994], Nöldeke and Schmidt [1995], and others, it is well-known that allowing for specific-performance contracts can lead, under certain circumstances, to efficient ex ante relationship-specific investments. Che and Hausch [1997] have shown, however, that when ex ante investments are cooperative (in the sense, that one party's investment benefits the other party), specific-performance contracts may not lead to first-best investment levels and may actually have no value.

11. The assumption of noncontractibility of ex ante investments could be relaxed to a case of partial contractibility. I have investigated an extension of the model in which production requires both contractible and noncontractible investments. If the marginal cost of noncontractible investments is increasing in the amount of contractible investments, the ability to set the contractible investments in the ex ante contract is not sufficient to solve the underinvestment problem discussed below, and the model delivers results analogous to the ones discussed in the main text. 
producer is equally locked in the relationship, and its investment in capital will also tend to be suboptimal. In either case, the extent of the underinvestment by each party will be inversely related to the share of surplus they obtain in the bargaining. As is standard in the literature, I model the ex post bargaining as a Generalized Nash Bargaining, which leaves the final-good producer with a fraction $\phi \in(0,1)$ of the ex post gains from trade.

As discussed in the Introduction, cost sharing will emerge in equilibrium whenever the bargaining power of suppliers is low. I hereafter assume the following.

Assumption 1. $\phi>1 / 2$.

Following the work of Grossman and Hart [1986] and Hart and Moore [1990], and contrary to the older transaction-cost literature, integration of the supplier does not eliminate the opportunistic behavior at the heart of the holdup problem. Bargaining will therefore occur even when the final-good producer and the supplier are integrated. The ex post distribution of surplus will, however, be sensitive to ownership structure. When the supplier is a stand-alone firm, the amount $x_{k}(i)$ is owned by the supplier, and thus if the two parties fail to agree on a division of the surplus, the final-good producer is left with nothing. Conversely, under integration, the manager of the final-good producer can always fire the manager of the supplying division and seize the amount of input already produced. The outside option for the final-good producer will therefore be higher under integration than under outsourcing. If the final-good producer could fully appropriate $x_{k}(i)$ under integration, there would be no surplus to bargain over after production, and the supplier would optimally set $L_{x, k}(i)=0$ (which of course would imply that $\left.x_{k}(i)=0\right)$. In that case, integration would never be chosen. To make things more interesting, I assume that by integrating the supplier, the final-good producer obtains the residual rights over only a fraction $\delta \in(0,1)$ of the amount of $x_{k}(i)$ produced, so that the surplus of the relationship remains positive even under integration. ${ }^{12}$ On the other hand, and because the component is completely specific to the final-good producer, the outside option for the intermediate input producer is zero regardless of ownership structure.

12. I take the fact that $\delta$ is strictly less than one as given, but this assumption could be rationalized in a richer framework (see Antràs [2003] for a rationale). 


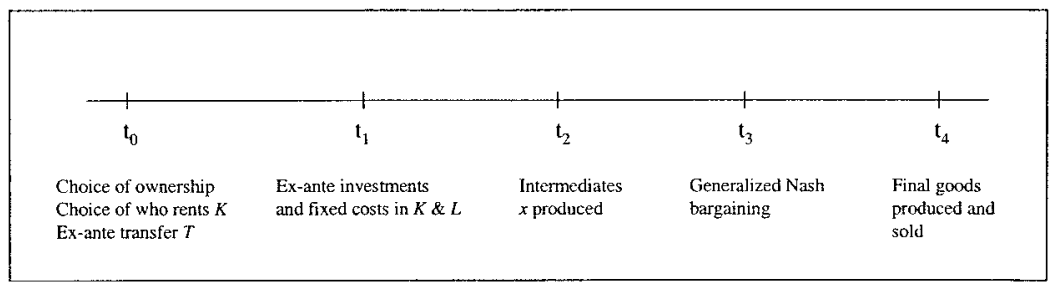

FIGURE III

Timing of Events

Figure III summarizes the timing of events. At $t_{0}$, the finalgood producer decides whether it wants to enter a given market, residual rights are assigned, the extent of cost sharing is decided, and the supplier makes a lump-sum transfer to the final-good producer. At $t_{1}$, firms choose their investments in capital and labor and also incur their fixed costs. At $t_{2}$, the final-good producer hands the specifications of the component (and perhaps the capital stock $K_{x, k}$ ) to its partner, and this latter produces the intermediate input, which can be of high or low quality. At $t_{3}$, the quality of the component becomes observable, and the two parties bargain over the division of the surplus. Finally, at $t_{4}$, the final good is produced and sold. For simplicity, I assume that agents do not discount the future between $t_{0}$ and $t_{4}$.

\section{II.B. Firm Behavior}

The model is solved by starting at $t_{4}$ and moving backwards. I will assume throughout the main text that final-good producers always choose to engage in capital cost sharing and thus incur the variable costs $r K_{x, k}(i)$. In Appendix 1, I formally show that Assumption 1 is in fact sufficient to ensure that this is the case in equilibrium.

The unit elasticity of substitution between varieties in industries $Y$ and $Z$ implies that we can analyze firm behavior in each industry independently. Consider industry $Y$, and suppose that at $t_{4}, n_{Y, V}$ pairs of integrated firms and $n_{Y, O}$ pairs of stand-alone firms are producing. ${ }^{13}$ Let $p_{Y, V}(i)$ be the price charged for variety $i$ by an integrating final-good producer, and let $p_{Y, O}(i)$ be the

13. Henceforth, a subscript $V$ will be associated with final-good producers that vertically integrate their suppliers. A subscript $O$ will be used for those that outsource the production of the input. 
corresponding price charged by a nonintegrating final-good producer. From equation (1), demand for any variety $i$ in industry $Y$ is given by

$$
y(i)=A_{Y} p_{Y}(i)^{-1 /(1-\alpha)},
$$

where

$$
A_{Y}=\frac{\mu E}{\int_{0}^{n Y, V} p_{Y, V}(j)^{-\alpha /(1-\alpha)} d j+\int_{0}^{n Y, O} p_{Y, O}(j)^{-\alpha /(1-\alpha)} d j},
$$

and $E$ denotes total spending in the economy. I treat the number of firms as a continuum, implying that firms take $A_{Y}$ as given.

Integrated pairs. Consider first the problem faced by a final-good producer and its integrated supplier. If the latter produces a high-quality intermediate input and the firms agree in the bargaining, the potential revenues from the sale of the final good are $R_{Y}(i)=p_{Y}(i) y(i)$. On the other hand, if the parties fail to agree in the bargaining, the final-good producer will only be able to sell an amount $\delta y(i)$ of output, which using (3) will translate into sale revenues equal to a fraction $\delta^{\alpha}$ of sale revenues in the case of an agreement. The ex post opportunity cost for the supplier is zero, implying that the ex post gains from trade are $\left(1-\delta^{\alpha}\right) R_{Y}(i)$. Because of the contract incompleteness, the surplus is divided among the parties at $t_{3}$. Generalized Nash Bargaining leaves the final-good division with its default option $\delta^{\alpha} R_{Y}(i)$ plus a fraction $\phi$ of the quasi rents, while the integrated supplier receives the remaining fraction $1-\phi$ of the quasi rents. Since both $\phi$ and $\delta$ are assumed to be strictly less than one, the supplier's ex post revenues from producing a high-quality input are strictly positive. Low-quality inputs will therefore never be produced at $t_{2}$. Rolling back to $t_{1}$, the final-good producer sets its investment in capital $K_{x, Y}(i)$ to maximize $\bar{\phi} R_{Y}(i)-r K_{x, Y}(i)$, where

$$
\bar{\phi}=\delta^{\alpha}+\phi\left(1-\delta^{\alpha}\right)>\phi .
$$

The program yields a best-response capital investment $K_{x, Y}(i)$ in terms of factor prices, the level of demand as captured by $A_{Y}$, and the investment in labor $L_{x, Y}(i)$. On the other hand, the integrated supplier simultaneously sets $L_{x, Y}(i)$ to maximize $(1-\bar{\phi}) R_{Y}(i)-$ $w L_{x, Y}(i)$, from which an analogous reaction function for $L_{x, Y}(i)$ is 
obtained. ${ }^{14}$ Solving for the intersection of these two best-response functions and plugging the equilibrium ex ante investments into (2) and (3), yields the optimal price for all varieties in industry $Y$ :

$$
p_{Y, V}=\frac{r^{\beta_{Y}} w^{1-\beta_{Y}}}{\alpha \bar{\phi}^{\beta_{Y}}(1-\bar{\phi})^{1-\beta_{Y}}} .
$$

Facing a constant elasticity of demand, the final-good producer charges a constant markup over marginal cost. The distortionary effect of incomplete contracting takes the form of a markup that is $1 / \bar{\phi}^{\beta_{Y}}(1-\bar{\phi})^{1-\beta_{Y}}$ times higher than the one that would be charged if contracts were complete. ${ }^{15}$

At $t_{0}$, the supplier makes a lump-sum transfer $T_{Y, V}$ to the final-good producer. As discussed above, this ex ante transfer exactly equals the supplier's profits, so that ex ante profits for an integrating final-good producer can be expressed as

$$
\pi_{F, V, Y}=\left(1-\alpha\left(1-\beta_{Y}\right)+\alpha \bar{\phi}\left(1-2 \beta_{Y}\right)\right) A_{Y} p_{Y, V}^{-\alpha /(1-\alpha)}-f r^{\beta_{Y}} w^{1-\beta_{Y}},
$$

where $p_{Y, V}$ is given in (5).

Nonintegrated pairs. Consider next a pair of stand-alone firms. In this case, the supplier is entitled to the residual rights of control over the amount of input produced at $t_{2}$. The ex post opportunity cost for the final-good producer is therefore zero in this case. As for the supplier, since the component is specific to the final-good producer, the value of $x_{Y}(i)$ outside the relationship is also zero. It follows that if the intermediate-input producer hands a component with the correct specification, the potential sale revenues $R_{Y}(i)$ will be entirely quasi rents. In the bargaining, the final-good producer will obtain a fraction $\phi$ of these ex post gains, and at $t_{1}$ it will choose $K_{x, Y}(i)$ to maximize $\phi R_{Y}(i)-$ $r K_{x, Y}(i)$. On the other hand, the supplier will set $L_{x, Y}(i)$ to maximize $(1-\phi) R_{Y}(i)-w L_{x, Y}(i)$. It is clear that the solution to the problem is completely analogous to that for pairs of integrated firms, with $\phi$ replacing $\bar{\phi}$ in equations (5) and (6). In particular, profits for a final-good producer that chooses to outsource the

14. The supplier could in principle find it optimal to complement the capital investment of the final-good division with some extra investment of its own. Nevertheless, if the two investments in capital are perfect substitutes in production, Assumption 1 is sufficient to ensure that the optimal capital investment of the supplier is zero (see Antràs [2003]).

15. At $t_{1}$ the two parties also choose how much capital and labor to rent in incurring the fixed costs. The particular values of these factor demands can be obtained by applying Shepard's lemma (e.g., $\left.L_{f, F, Y}=\left(1-\beta_{Y}\right) f_{F}(w / r)^{-\beta_{Y}}\right)$. 
production of the intermediate input are

$$
\pi_{F, Y, O}=\left(1-\alpha\left(1-\beta_{Y}\right)+\alpha \phi\left(1-2 \beta_{Y}\right)\right) A_{Y} p_{Y, O}^{-\alpha /(1-\alpha)}-f r^{\beta_{Y}} w^{1-\beta_{Y}},
$$

where $p_{Y, O}=r^{\beta_{Y}} w^{1-\beta_{Y}} /\left(\alpha \phi^{\beta_{Y}}(1-\phi)^{1-\beta_{Y}}\right)$.

It is useful to compare the present setup to one in which the quality of the component was verifiable, so that quality-contingent contracts could be enforced. In such a case, the two parties would bargain over the division of the surplus upon entry, and the contract would not be renegotiated ex post. The investments in capital and labor would be set to maximize the total surplus of the relationship, which is given by $p_{Y}(i) y(i)-r K_{x, Y}(i)-w L_{x, Y}(i)-$ $f r^{\beta_{Y}} w^{1-\beta_{Y}}$. It is straightforward to check that the impossibility of writing enforceable contracts leads to underinvestment in both $K_{x, Y}$ and $L_{x, Y}$. Underinvestment stems from the fact that, with incomplete contracts, producers receive only a fraction of the marginal return to their ex ante investments. The inefficiency is depicted in Figure IV. The curves $F^{*}$ and $S^{*}$ represent the reaction functions $K_{x, Y}^{*}\left(L_{x, Y}\right)$ and $L_{x, Y}^{*}\left(K_{x, Y}\right)$ under complete contracts, with the corresponding equilibrium in point $A$. Similarly, $B$ and $C$ depict the incomplete-contract equilibria corresponding to integration and outsourcing, respectively. Crucially, the underinvestment in labor relative to that in capital tends to be greater

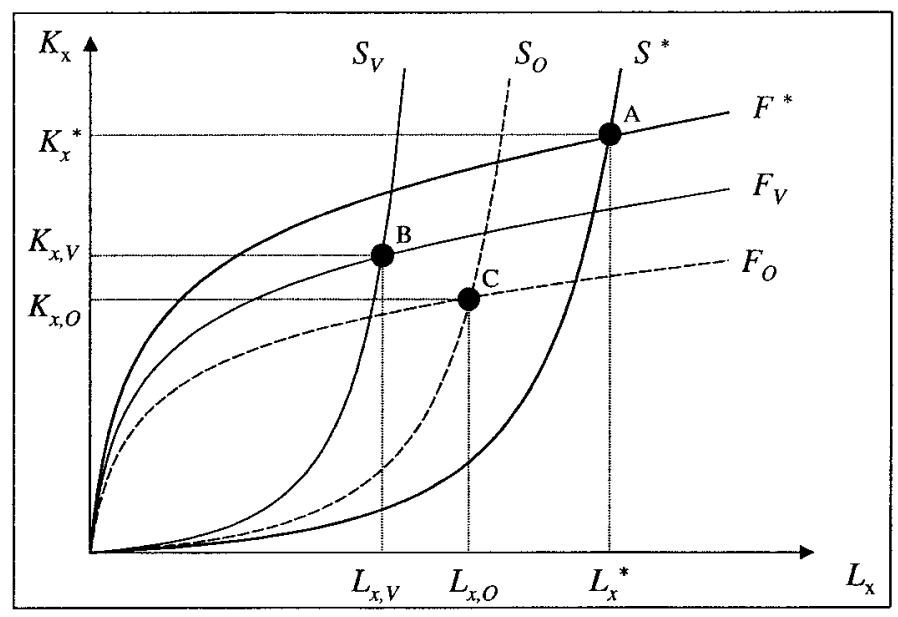

FIGURE IV

Complete Versus Incomplete Contracts 
under integration that under outsourcing. ${ }^{16}$ This follows from the fact that under integration, the supplier has a relatively weaker bargaining power and thus receives a smaller fraction of the marginal return to its ex ante investment. By a similar argument, the investment in capital tends to be relatively more inefficient under outsourcing than under integration.

\section{II.C. Factor Intensity and Ownership Structure}

At $t_{0}$, the final-good producer chooses the ownership structure that maximizes its ex ante profits. Let $\Theta\left(\beta_{k}\right)$ denote the ratio of operating profits under vertical integration to those under outsourcing. Using equations (6), (7), and $\bar{\phi}=\delta^{\alpha}+\phi\left(1-\delta^{\alpha}\right)$, this ratio can be expressed as

$$
\begin{aligned}
& \Theta\left(\beta_{k}\right)=\left(1+\frac{\alpha(1-\phi) \delta^{\alpha}\left(1-2 \beta_{k}\right)}{1-\alpha\left(1-\beta_{k}\right)+\alpha \phi\left(1-2 \beta_{k}\right)}\right) \\
& \quad \times\left(1+\frac{\delta^{\alpha}}{\phi\left(1-\delta^{\alpha}\right)}\right)^{\alpha \beta_{k} /(1-\alpha)}\left(1-\delta^{\alpha}\right)^{\alpha /(1-\alpha)} .
\end{aligned}
$$

As I prove in Appendix 2, the attractiveness of integration, as measured by $\Theta\left(\beta_{k}\right)$, is increasing in the capital intensity of intermediate input production; i.e., $\Theta^{\prime}\left(\beta_{k}\right)>0$. Intuitively, the relatively higher underinvestment in capital associated with outsourcing is more value-reducing, the higher the capital intensity in production. Furthermore, it can be shown that for low enough capital intensities, outsourcing yields higher profits than integration $(\Theta(0)<1)$, while for high enough capital intensities, the converse is true $(\Theta(1)>1) .{ }^{17}$ It thus follows:

Proposition 1. There exists a unique threshold capital intensity $\hat{\beta} \in(0,1)$ such that all firms with $\beta_{k}<\hat{\beta}$ choose to outsource production of the intermediate input (i.e., $\Theta\left(\beta_{k}\right)<1$ ), while

16. By this I mean that $\left(L_{x, Y}^{*} / L_{x, Y, V}\right) /\left(K_{x, Y}^{*} / K_{x, Y, V}\right)>\left(L_{x, Y}^{*} / L_{x, Y, O}\right) /\left(K_{x, Y}^{*} /\right.$ $\left.K_{x, Y, O}\right)$. Note that this also implies that controlling for industry characteristics, integrated suppliers should be using a higher capital-labor ratio in production than nonintegrated ones. This is consistent with the results of some empirical studies, discussed in Caves [1996, pp. 230-231] and Dunning [1993, p. 296], that compare capital intensity in overseas subsidiaries of multinational firms with that of independent domestic firms in the host country.

17. An important point to notice here is that $\Theta\left(\beta_{k}\right)$ is not a function of factor prices. This follows directly from the assumption of Cobb-Douglas technology and isolates the partial-equilibrium decision to integrate or outsource from any potential general-equilibrium feedbacks. This implied block-recursiveness is a useful property for solving the model sequentially, but the main results should be robust to more general specifications for technology. 
all firms with $\beta_{k}>\hat{\beta}$ choose to integrate their suppliers (i.e., $\left.\Theta\left(\beta_{k}\right)>1\right)$. Only firms with capital intensity $\hat{\beta}$ are indifferent between these two options.

Proof. See Appendix 2.

The logic of this result lies at the heart of Grossman and Hart's [1986] seminal contribution. In a world of incomplete contracts, ex ante efficiency dictates that residual rights should be controlled by the party undertaking a relatively more important investment. If production of the intermediate input requires mostly labor, the investment made by the final-good producer will be relatively small, and thus it will be optimal to assign the residual rights of control to the supplier in order to alleviate the underinvestment in the labor input (see Figure IV). Conversely, when the capital investment is important, the final-good producer will optimally choose to tilt the bargaining power in its favor by obtaining these residual rights, thus giving rise to vertical integration. $^{18}$

Proposition 1 advances a rationale for the first fact identified in the introduction. To the extent that vertical integration of suppliers occurs mostly in capital-intensive industries, one would expect the share of intrafirm trade to be relatively higher in those industries. Nevertheless, Proposition 1 cannot by itself justify the trade pattern in Figure I. An explanation of this fact requires a proper modeling of international trade flows, which I carry out in Section III.

\section{II.D. Industry Equilibrium}

Without loss of generality, consider next the industry equilibrium in sector $Y$. In equilibrium, free entry implies that no firm makes positive expected profits. In principle, three equilibrium modes of organization are possible: (i) a mixed equilibrium with some varieties being produced by integrated pairs and others by nonintegrated pairs; (ii) an equilibrium with pervasive integra-

18. Equation (8) lends itself to other comparative static exercises. For instance, it is possible to show that $\Theta\left(\beta_{k}\right)$ is a decreasing function of $\phi$, which by the implicit function theorem implies that the cutoff $\hat{\beta}$ is an increasing function of $\phi$. To understand this result, notice that an increase in $\phi$ shifts bargaining power from the supplier to the final-good producer regardless of ownership structure (since $\bar{\phi}$ increases with $\phi$ ). It thus follows that increasing $\phi$ necessarily worsens the incentives for the supplier. To compensate for this, the final-good producer will now find it profitable to outsource in a larger measure of capital intensities. The partial derivative of $\Theta\left(\beta_{k}\right)$ with respect to $\alpha$ and $\delta$ is in general ambiguous (see Antràs [2003] for details). 
tion in which no final-good producer finds it profitable to outsource the production of the intermediate input; and (iii) an equilibrium with pervasive outsourcing in which no final-good producer chooses to vertically integrate its supplier. The assumption that all firms in a given industry share the same capital intensity greatly simplifies the analysis. In particular, a mixed equilibrium in industry $Y$ can only exist in a knife-edge case, namely when $\beta_{Y}=\hat{\beta}$. The equilibrium in industry $Y$ is either one with pervasive integration when $\beta_{Y}>\hat{\beta}$, or one with pervasive outsourcing when $\beta_{Y}<\hat{\beta}$.

Because a mixed equilibrium does not generically exist, we can focus on a characterization of the two other types of equilibria. Consider first an equilibrium in which only integrating finalgood producers enter the market. As discussed above, the ex ante transfer $T_{Y, V}$ ensures that suppliers always break even. If no final-good producer outsources the production of $x_{Y}$, all firms will charge a price for $y(i)$ given by equation (5). Since $n_{Y, O}=0$, equation (4) simplifies to $A_{Y, V}=\mu E p_{Y, V}^{\alpha /(1-\alpha)} / n_{Y, V}$. Plugging this expression into equation (6) and setting $\pi_{F, V}$ to 0 as dictated by free entry, yields the following expression for the equilibrium number of vertically integrated pairs:

$$
n_{Y, V}=\frac{1-\alpha\left(1-\beta_{Y}\right)+\alpha \bar{\phi}\left(1-2 \beta_{Y}\right)}{f r^{\beta_{Y}} w^{1-\beta_{Y}}} \mu E .
$$

Naturally, the equilibrium number of varieties in industry $Y$ depends positively on total spending in the industry and negatively on fixed costs.

Consider next an equilibrium with pervasive outsourcing. In such an equilibrium every firm charges a price given by $p_{Y, O}$ which makes equation (4) simplify to $A_{Y, O}=\mu E p_{Y, O}^{\alpha /(1-\alpha)} / n_{Y, O}$. Imposing again free entry on equation (7) yields the equilibrium number of pairs undertaking outsourcing,

$$
n_{Y, O}=\frac{1-\alpha\left(1-\beta_{Y}\right)+\alpha \phi\left(1-2 \beta_{Y}\right)}{f r^{\beta Y} w^{1-\beta Y}} \mu E .
$$

\section{II.E. General Equilibrium}

Having described the equilibrium in a particular industry, we can now move to the general equilibrium of the closed economy, in which income equals spending:

$$
E=r K+w L,
$$


and the capital and labor markets clear. By Walras' law we can focus on the equilibrium in the labor market. Letting $L_{Y}$ and $L_{Z}$ denote total labor demand by each pair in industries $Y$ and $Z$, labor market clearing requires $n_{Y} L_{Y}+n_{Z} L_{Z}=L$. We can decompose $L_{Y}$ into three components, depending on the equilibrium mode of organization. In an equilibrium with pervasive integration,

$$
L_{Y}=L_{x, Y, V}+L_{f, F, Y}+L_{f, S, Y} .
$$

The first term is the total amount of labor hired by integrated suppliers for the manufacturing of intermediate inputs. The remaining terms are the amounts of labor hired to cover fixed costs by final-good producers and suppliers. Plugging the equilibrium values for labor demands into equation (12), and using (11) and the equilibrium value of $n_{Y, V}$ to simplify, results in

$$
w n_{Y, V} L_{Y}=\left(1-\beta_{Y}\right)\left(1-\alpha \beta_{Y}(2 \bar{\phi}-1)\right) \mu(r K+w L) .
$$

Similarly, in an equilibrium with pervasive outsourcing,

$$
w n_{Y, O} L_{Y}=\left(1-\beta_{Y}\right)\left(1-\alpha \beta_{Y}(2 \phi-1)\right) \mu(r K+w L) .
$$

Equations (13) and (14) imply that the share of income that labor receives is sensitive to the equilibrium mode of organization. Given the assumption of Cobb-Douglas technology, in a world of complete contracts, the share of income accruing to labor in industry $Y$ would be $\mu\left(1-\beta_{Y}\right)$. With incomplete contracts, the share received by labor will be larger or smaller than $\mu\left(1-\beta_{Y}\right)$ depending on whether $\phi$ or $\bar{\phi}$ are smaller or greater than $1 / 2$.

To set the stage for an analysis of the share of intrafirm trade in total trade, I make the following assumption.

Assumption 2. $\beta_{Y}>\hat{\beta}>\beta_{Z}$.

In words, I assume that the equilibrium in industry $Y$ is one with pervasive integration, while that in industry $Z$ is one of pervasive outsourcing. It is useful to define the shares of income that accrue to capital in each sector, which using equations (13) and (14) are given by $\widetilde{\beta_{Y}}=\beta_{Y}\left(1+\alpha\left(1-\beta_{Y}\right)(2 \bar{\phi}-1)\right)$ and $\widetilde{\beta_{Z}}=$ $\beta_{Z}\left(1+\alpha\left(1-\beta_{Z}\right)(2 \phi-1)\right)$. ${ }^{19}$ Denoting the average labor share in the economy by $\sigma_{L} \equiv \mu\left(1-\widetilde{\beta_{Y}}\right)+(1-\mu)\left(1-\widetilde{\beta_{Z}}\right)$ and impos-

19. Notice that $\beta_{Y}>\beta_{Z}$ implies that $\widetilde{\beta_{Y}}>\widetilde{\beta_{Z}}$ and incomplete contracting does not create factor intensity reversals. 
ing the condition $n_{Y, V} L_{Y}+n_{Z, O} L_{Z}=L$, the equilibrium wagerental ratio in the economy can be expressed as

$$
\frac{w}{r}=\frac{\sigma_{L}}{1-\sigma_{L}} \frac{K}{L} .
$$

Because of the unit elasticity of substitution in production, the equilibrium wage-rental ratio is a linear function of the aggregate capital-labor ratio. The factor of proportionality is equal to the average labor share in the economy divided by the average capital share. Under Assumption 1 the average labor share and the equilibrium wage-rental ratio are depressed relative to their values in a world with complete contracts. ${ }^{20}$

\section{The Multicountry Model: Capital Abundance and Intrafirm Trade}

Suppose now that the closed economy described above is split into $J \geq 2$ countries, with each country receiving an endowment $K^{j}$ of capital and an endowment $L^{j}$ of labor. Factors of production are internationally immobile. Countries differ only in their factor endowments. In particular, individuals in all $J$ countries have identical preferences as specified in equation (1) and share access to the same technology in equation (2). The parameters $\phi$ and $\delta$ are also assumed to be identical everywhere. Countries are allowed to trade intermediate inputs at zero cost, while final goods are instead assumed to be nontradable, so that each final-good producer has a (costless) plant in each of the $J$ countries. ${ }^{21} \mathrm{Va}$ rieties of intermediate inputs will instead be produced in only one location in order to exploit economies of scale. I assume that for all $j \in J$, the capital-labor ratio $K^{j} / L^{j}$ is not too different from $K / L$, so that factor price equalization (FPE) holds, and the equilibrium prices and aggregate allocations are those of the integrated economy described above. Below, I derive both necessary and sufficient conditions for FPE to be achieved.

20. Intuitively, with $\phi>1 / 2$, the underinvestment in labor is relatively more severe than the underinvestment in capital. Because factors are supplied inelastically, the relatively lower demand for labor tends to push down its price and its share in total income.

21 . Because final goods are costlessly produced, the model cannot endogenously pin down where their production is located. Assuming that they are not traded resolves this indeterminacy. In Antràs [2003] I showed that the main result goes through under alternative setups that equally resolve the indeterminacy (see footnote 27 for more on this). 
This section is in two parts. I first study the international location of production of intermediate inputs and show how the cross-country differences in factor endowments naturally give rise to cross-country differences in industry structure. I then analyze the implied patterns of international trade and discuss the determinants of its intrafirm component.

\section{III.A. Pattern of Production}

Because countries differ only in their factor endowments, the cutoff capital intensity $\hat{\beta}$ will be identical in all countries, and by Assumption 2, suppliers in industry $Y$ will be vertically integrated while those in industry $Z$ will remain nonintegrated. The factor market clearing conditions in country $j \in J$ can be written as

$$
\begin{aligned}
& n_{Y}^{j}\left(K_{x, Y}^{j}+K_{f, F, Y}^{j}+K_{f, S, Y}^{j}\right)+n_{Z}^{j}\left(K_{x, Z}^{j}+K_{f, F, Z}^{j}+K_{f, S, Z}^{j}\right)=K^{j} \\
& n_{Y}^{j}\left(L_{x, Y}^{j}+L_{f, F, Y}^{j}+L_{f, S, Y}^{j}\right)+n_{Z}^{j}\left(L_{x, Z}^{j}+L_{f, F, Z}^{j}+L_{f, S, Z}^{j}\right)=L^{j},
\end{aligned}
$$

where $n_{k}^{j}$ refers now to the number of industry $k$ varieties of intermediate inputs produced in country $j .{ }^{22}$ It is straightforward to check that factor demands for each variety depend only on worldwide identical parameters and on aggregate prices, which because of FPE are also common in all countries. This implies that differences in the pattern of production between countries will be channelled through the number of industry varieties produced in each country. Plugging the equilibrium factor demands into (16) and (17) and combining these two expressions yields the number of varieties of intermediate inputs produced in country $j$ :

$$
\begin{gathered}
n_{Y}^{j}=\left(\left(1-\widetilde{\beta_{Z}}\right)\left(1-\sigma_{L}\right) \frac{K^{j}}{K}-\widetilde{\beta_{Z}} \sigma_{L} \frac{L^{j}}{L}\right) \frac{n_{Y}}{\left(\widetilde{\beta_{Y}}-\widetilde{\beta_{Z}}\right) \mu} \\
n_{Z}^{j}=\left(\widetilde{\beta_{Y} \sigma_{L}} \frac{L^{j}}{L}-\left(1-\widetilde{\beta_{Y}}\right)\left(1-\sigma_{L}\right) \frac{K^{j}}{K}\right) \frac{n_{Z}}{\left(\widetilde{\beta_{Y}}-\widetilde{\beta_{Z}}\right)(1-\mu)},
\end{gathered}
$$

where $n_{Y}$ is given by equation (9) and $n_{Z}$ by equation (10) with $\beta_{Z}$ replacing $\beta_{Y}$. Equation (18) states that a given country $j \in J$ will produce a larger measure of intermediate-input varieties in industry $Y$, the larger its capital-labor ratio. Conversely, from equa-

22. To simplify notation, I drop all subscripts associated with the equilibrium mode of organization. For instance, I denote the equilibrium number of varieties produced in industry $Y(Z)$ and country $j$ by $n_{Y}^{j}\left(n_{Z}^{j}\right)$ instead of $n_{Y, V}^{j}\left(n_{Z, O}^{j}\right)$. 
tion (19) the measure of industry $Z$ varieties it produces is a decreasing function of its capital-labor ratio. Note also that for a given $K^{j} / L^{j}$ both $n_{Y}^{j}$ and $n_{Z}^{j}$ are increasing in the size of country $j$, as measured by its share in world GDP, $s_{j} \equiv\left(r K^{j}+w L^{j}\right) /(r K+$ $w L)$. In fact, it is easy to check that $n_{Y}^{j}>s^{j} n_{Y}$ if and only if $K^{j} / L^{j}>K / L$, and $n_{Z}^{j}>s^{j} n_{Z}$ if and only if $K^{j} / L^{j}<K / L$. In words, capital- (labor)-abundant countries tend to capture a fraction of the world production of input varieties in the capital (labor)intensive industry that exceeds their share in world income.

For the above allocation to be consistent with FPE, it is necessary and sufficient that $n_{Y}^{j}>0$ and $n_{Z}^{j}>0$ for all $j \in J$, i.e., that no country fully specializes in any one sector. ${ }^{23}$ Using equations (18) and (19), this condition can be written as

Assumption 3.

$$
\bar{\kappa}=\frac{\widetilde{\beta_{Y}} \sigma_{L}}{\left(1-\widetilde{\beta_{Y}}\right)\left(1-\sigma_{L}\right)}>\frac{K^{j} / L^{j}}{K / L}>\frac{\widetilde{\beta_{Z}} \sigma_{L}}{\left(1-\widetilde{\beta_{Z}}\right)\left(1-\sigma_{L}\right)}=\underline{\kappa} \text { for all } j \in J .^{24}
$$

Figure $\mathrm{V}$ provides a graphical representation of the production pattern for the case of two countries, the North $(N)$ and the South $(S)$. The graph should be familiar to readers of Helpman and Krugman [1985]. $O^{N}$ and $O^{S}$ represent the origins for the North and the South, respectively. The vectors $O^{N} Y$ and $O^{N} Z$ represent world employment of capital and labor in industries $Y$ and $Z$ in the equilibrium of the integrated economy. The set of factor endowments consistent with FPE corresponds to the set of points inside the parallelogram $O^{N} Y O^{S} Z$. Point $E$ defines the distribution of factor endowments. Line $B B^{\prime}$ goes through point $E$ and has a slope of $w / r$. The relative income of each country is thus held fixed for all points along this line and inside the FPE set. To map this figure to the pattern of production described above, I follow Helpman and Krugman [1985] in choosing units of measurement so that $\left\|O^{N} Y\right\|=n_{Y} y,\left\|O^{N} Z\right\|=n_{Z} z$, and $\left\|O^{N} O^{S}\right\|=$ $E=r K+w L$. With the first two normalizations, we can graphi-

23. To understand necessity, notice that when factor prices depend only on world factor endowments, the capital-labor ratio in production is fixed and identical for all countries. Therefore, a given country cannot employ all its factors by producing in only one industry except in the knife-edge case in which its endowment of $K^{j}$ and $L^{j}$ exactly match that industry's factor intensity. For a discussion of sufficiency see Helpman and Krugman [1985, pp. 13-14].

24 . The upper bound $\bar{\kappa}$ is greater than one, while the lower bound $\kappa$ is smaller than one. Assumption 3 thus requires the capital-labor ratio $K^{j} / L^{j}$ to be sufficiently similar to $K / L$. 


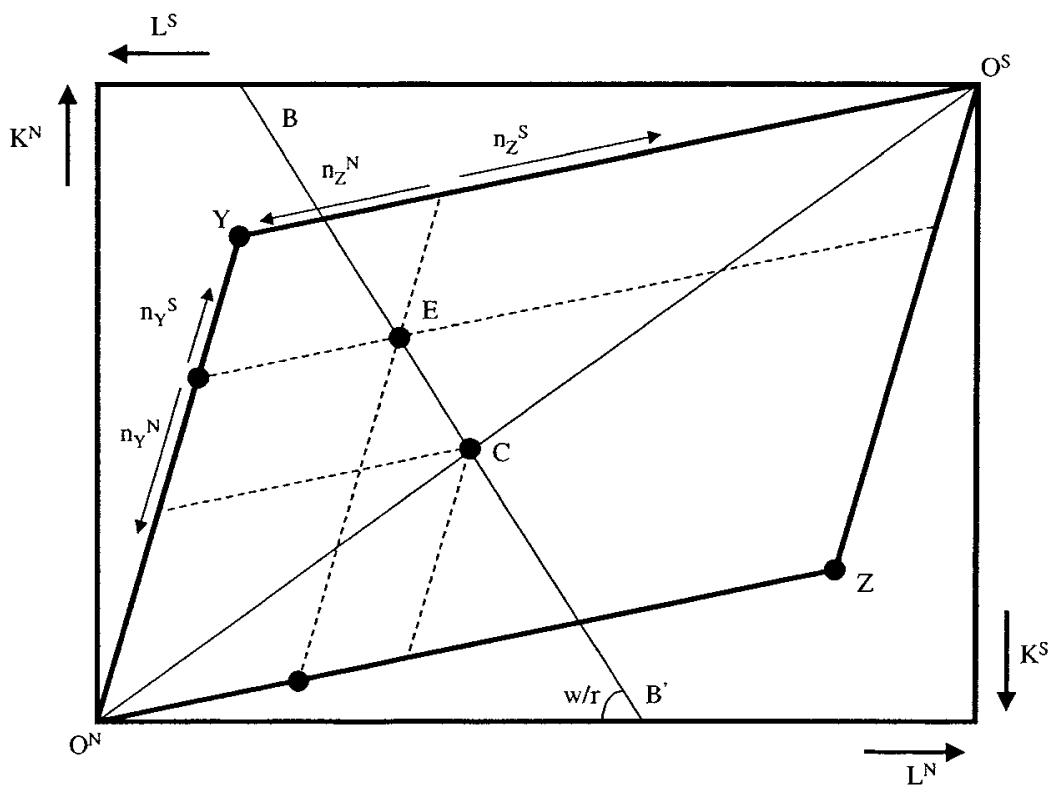

Figure V

Pattern of Production for $J=2$

cally determine the number of varieties of intermediate inputs produced in each country. Moreover, with the last normalization we can write $s^{N}=\left\|O^{N} C\right\| /\left\|O^{N} O^{S}\right\|$. Basic geometry then implies that $n_{Y}^{N}>s^{N} n_{Y}$ and $n_{Z}^{N}<s^{N} n_{Z}$, which is what we expected given that, in the graph, the North is capital-abundant relative to the South.

So far, I have assumed that factors of production are internationally immobile. I therefore have not allowed final-good producers to rent the capital stock in their home country and export it to the country where intermediates are produced. Allowing for such international factor movements would not invalidate the equilibrium described above. In fact, by equalizing factor prices everywhere, international trade in intermediate inputs eliminates the incentives for capital to flow across countries. ${ }^{25}$

25. More generally, I only require that the costs of capital mobility are higher than the costs of trading goods, so that international differences in rates of return are arbitraged away through trade flows rather than through capital flows (cf. Mundell [1957]). 


\section{III.B. Pattern of Trade}

Having described the international location of production of intermediate inputs, we can finally move to the study of trade patterns. Since the final good is nontradable, the entire volume of world trade will be in intermediate inputs. Before describing these flows in more detail, we must first confront the problem of how to value them. The fact that contracts are incomplete implies that there is no explicit price for these varieties. Because all variable costs are incurred in the country where the input is produced, a plausible assumption is to value these intermediates at average cost. And because the final good is produced at no cost, the implicit price of an intermediate input is simply $p_{Y, V}$ in industry $Y$ and $p_{Z, O}$ in industry $Z{ }^{26}$

Without loss of generality, consider now a given country $N$ 's imports from another country $S$. Country $N$ will host $n_{Y}+n_{Z}$ plants producing final-good varieties. Of the $n_{Y}$ plants in industry $Y$, a measure $n_{Y}^{S}$ will be importing the intermediate input from their integrated suppliers in country $S$. This volume of trade will thus be intrafirm trade. On the other hand, of the $n_{Z}$ plants in industry $Z$, a measure $n_{Z}^{S}$ will be importing the input from independent suppliers in country $j \neq N$. These transactions will thus occur at arm's length. Furthermore, because preferences are homothetic and identical everywhere, consumers in country $N$ will incur a fraction $s^{N}$ of world spending on each variety. It thus follows that the total volume of $N$ imports from $S$ will be $s^{N}\left(n_{Y}^{S} p_{Y} y+n_{Z}^{S} p_{Z} z\right)$, or simply

$$
M^{N, S}=s^{N} s^{S}(r K+w L) .
$$

Similarly, the total volume of country $N$ exports to country $S$ is $s^{S} s^{N}(r K+w L)$, implying that trade is balanced. Since both industries produce differentiated goods, for a given $s^{N}+s^{S}$, the volume of bilateral trade is maximized when both countries are of equal size (cf. Helpman and Krugman [1985]).

Consider next the composition of imports. Because only in industry $Y$ will intermediate inputs flow within firm boundaries, the volume of country $N$ intrafirm imports from $S$ is given by

26. As suggested by a referee, intermediates could alternatively be valued according to the supplier's average revenues. In such case, the implicit prices would be $(1-\bar{\phi}) p_{Y, V}$ and $(1-\phi) p_{Z, O}$. This would reduce the value of trade flows, with a disproportionate reduction in industry $Y$. As a result, the link between factor endowments and the volume of trade established in Proposition 2 below would be attenuated. 
$M_{i-f}^{N, S}=s^{N} n_{Y}^{S} p_{Y} y$. Plugging the equilibrium value for $n_{Y}^{S}$ and rearranging, it is possible to express intrafirm imports as

$$
M_{i-f}^{N, S}=s^{N} s^{S}(r K+w L) \frac{\left(1-\widetilde{\beta_{Z}}\right)\left(1-\sigma_{L}\right)\left(K^{S} / L^{S}\right)-\widetilde{\beta_{Z}} \sigma_{L}(K / L)}{\left(\widetilde{\beta_{Y}}-\widetilde{\beta_{Z}}\right)\left(\left(1-\sigma_{L}\right)\left(K^{S} / L^{S}\right)+\sigma_{L}(K / L)\right)} .
$$

Intrafirm imports are increasing in the size of both the importing and exporting countries and, from simple differentiation of (21), are also increasing in the capital-labor ratio of the exporting country.

Lemma 1. For any pair of countries $N, S \in J$ with $S \neq N$, the volume of $N$ 's intrafirm imports from $S, M_{i-f}^{N, S}$, is, for a given size $s^{N}$ of the importing country, an increasing function of the capital-labor ratio $K^{S} / L^{S}$ and the size $s^{S}$ of the exporting country. Furthermore, for a given $K^{S} / L^{S}$ and $s^{S}, S_{i-f}^{N, S}$ is also increasing in the size $s^{N}$ of the importing country.

Figure VI depicts combinations of factor endowments that yield the same volume of intrafirm imports $M_{i-f}^{N, S}$, for the case in

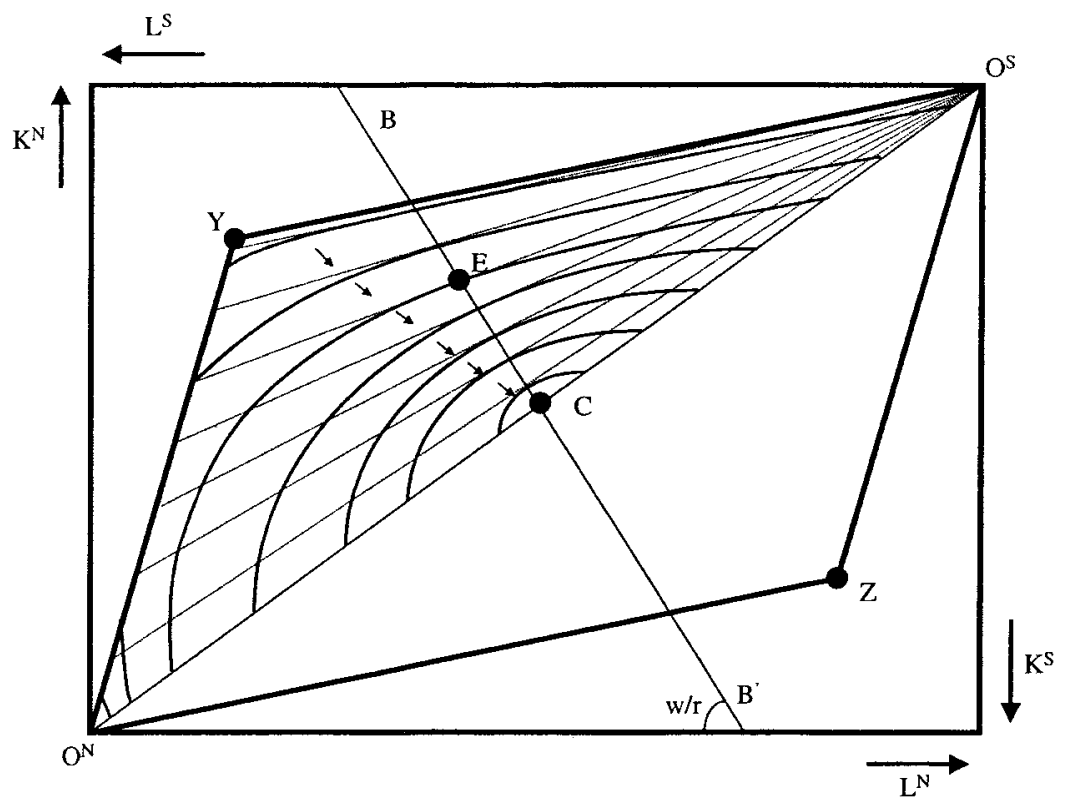

Figure VI

Volume of Intrafirm Imports 
which there are only two countries, $N$ and $S$. The arrows in the graph point in the direction of increasing intrafirm imports. Point $C$ is such that $\left\|O^{N} C\right\|=\left\|C O^{S}\right\|$, implying that the line $B B^{\prime}$ contains all points for which $s^{N}=s^{S}$. The graph shows how for a given capital-labor ratio of the exporting South, $M_{i-f}^{N, S}$ is maximized when the two countries are of equal size. On the other hand, for a given relative size of the two countries, $M_{i-f}^{N, S}$ is increasing in the capital-labor ratio of the exporting country.

Next, let $S_{i-f}^{N, S}$ denote the share of intrafirm imports in total imports; i.e., $S_{i-f}^{N, S} \equiv M_{i-f}^{N, S} / M^{N, S}$. Dividing equation (21) by (20) yields

$$
S_{i-f}^{N, S}=\frac{\left(1-\widetilde{\beta_{Z}}\right)\left(1-\sigma_{L}\right)\left(K^{S} / L^{S}\right)-\widetilde{\beta_{Z}} \sigma_{L}(K / L)}{\left(\widetilde{\beta_{Y}}-\widetilde{\beta_{Z}}\right)\left(\left(1-\sigma_{L}\right)\left(K^{S} / L^{S}\right)+\sigma_{L}(K / L)\right)} .
$$

Notice that Assumption 3 ensures that $S_{i-f}^{N, S} \in(0,1)$. When $K^{S} / L^{S}$ goes to $\kappa \cdot K / L$, the South only produces varieties of intermediates in industry $Z$, and thus $S_{i-f}^{N, S}$ goes to 0 . Similarly, when $K^{S} / L^{S}$ goes to $\bar{\kappa} \cdot K / L$, the South fully specializes in industry $Y$, and thus $S_{i-f}^{N, S}$ goes to 1 . Furthermore, simple differentiation of (22) reveals the following.

Proposition 2. For any pair of countries $N, S \in J$ with $S \neq N$, the share $S_{i-f}^{N, S}$ of intrafirm imports in total $N$ 's imports from $S$ is an increasing function of the capital-labor ratio $K^{S} / L^{S}$ of the exporting country. Furthermore, for a given $K^{S} / L^{S}, S_{i-f}^{N, S}$ is unaffected by the relative size of each country.

The first statement is one of the key results of the paper. In a world of international trade and specialization, the pattern of Figure II in the Introduction is a direct implication of the pattern in Figure I. Figure VII provides a graphical illustration of Proposition 2 for the case of two countries. Since $S_{i-f}^{N, S}$ is uniquely determined by $K^{S} / L^{S}$, the sets of points for which $S_{i-f}^{N, S}$ is constant are simple straight lines from the origin of the South. The arrows indicate that for any relative size of each country, $S_{i-f}^{N, S}$ is increasing in $K^{S} / L^{S}{ }^{27}$

27. In Antràs [2003], I study the robustness of the results to alternative assumptions on the tradability of final goods. For example, I consider the case of a probabilistic location of final-good production. Final-good varieties can be traded, but each variety is produced in only one randomly chosen location. If the probability that a given final-good variety is produced in a certain country is proportional to the size of the country, but is independent of the specific variety, 


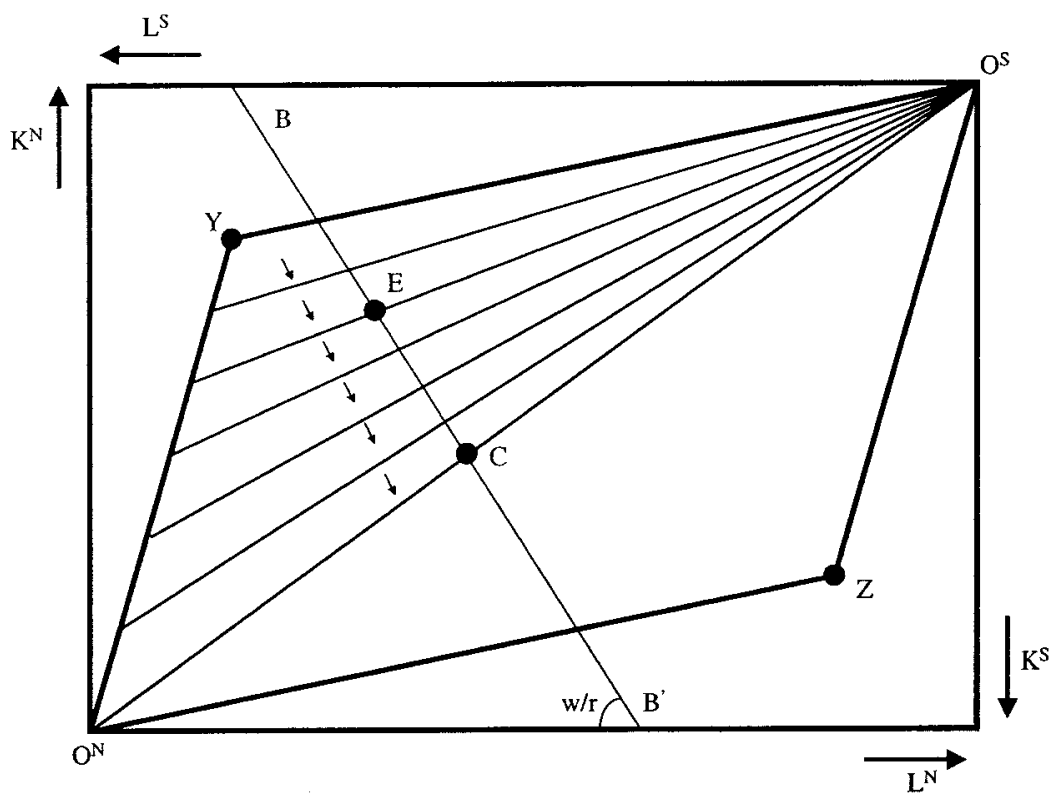

Figure VII

Share of Intrafirm Imports

\section{ECONOMEtric Evidence}

In this section I use data on intrafirm and total U. S. imports to test more formally the empirical validity of the main results of the paper. I first study the relationship between factor intensity and the share of intrafirm imports in total imports, and show that the clear correlation in Figure I is not driven by other omitted variables. Next, I move on to the relationship between relative factor endowments and the share of intrafirm imports. The link predicted by Proposition 2 is confirmed even when controlling for other factors that could reasonably be expected to affect this share. Finally, I analyze the determinants of the total volume of intrafirm imports and show that, consistently with Lemma 1,

its industry, and the location of intermediate-input production, the share of intrafirm imports is again given by equation (22) up to a constant factor of proportionality. 
total intrafirm imports are significantly affected by both the capital-labor ratio and the size of the exporting country.

\section{IV.A. Specification}

The first hypothesis to test is that the share of intrafirm imports is higher, the higher the capital intensity of the exporting industry. The model presented above actually has the stark prediction that the share should be 0 for industries with capital intensity $\beta_{k}$ below a certain threshold $\hat{\beta}$ and 1 for industries with $\beta_{k}>\hat{\beta}$. As I illustrate in Antràs [2003], however, if the statistician disaggregates the data into $M$ industries following a criterion different from the one dictated by preferences or technology, the model can be shown to predict a smooth positive association between the recorded share of intrafirm imports in a given industry and the recorded average capital intensity in the industry. ${ }^{28}$ In the econometric results below, I report estimates from regressions of the form,

$$
\ln \left(S_{i-f}^{U S, R O W}\right)_{m}=\theta_{1}+\theta_{2} \ln (K / L)_{m}+W_{m}^{\prime} \theta_{3}+\epsilon_{m},
$$

where $\left(S_{i-f}^{U S, R O W}\right)_{m}$ is industry $m$ 's share of intrafirm imports in total U. S. imports from the rest of the world, $(K / L)_{m}$ is the average capital-labor ratio in the industry, $W_{m}$ is a vector of controls, and $\epsilon_{m}$ is an orthogonal error term. The vector $W_{m}$ is included to control for other possible industry-specific determinants of the integration decision. Since I observe the share $\left(S_{i-f}\right)_{m}$ in four different years, I also include industry effects in the regressions below. In light of Proposition 1, I hypothesize that $\theta_{2}>0$.

The second hypothesis that I test is that, in the cross section of countries, the share of intrafirm imports in total imports is higher, the higher the capital-labor ratio of the exporting country. Equation (22) actually provides a closed-form solution for this relationship. Denoting the importing country by US and the exporting country by $j$, and applying a log-linear approximation to $(22)$ leads to the following specification: ${ }^{29}$

28. As pointed out by a referee, the smooth pattern in Figure I could also be the result of idiosyncratic preferences by firms concerning the outsourcing decision. An explicit modeling of such firm-level heterogeneity would, however, greatly complicate the general-equilibrium analysis.

29. In particular, I log-linearize (22) around $K^{j} / L^{j}=K / L$, and obtain

$$
\left.\ln S_{i-f}^{U S, j}\right|_{K^{j} / L^{j}=K / L} \simeq \ln (\mu)+\frac{\left(1-\sigma_{L}\right) \sigma_{L}}{1-\sigma_{L}-\widetilde{\beta_{Z}}}\left(\ln \frac{K^{j}}{L^{j}}-\ln \frac{K}{L}\right) .
$$




$$
\ln \left(S_{i-f}^{U S, j}\right)=\gamma_{1}+\gamma_{2} \ln \left(K^{j} / L^{j}\right)+\gamma_{3} \ln \left(L^{j}\right)+W_{j}^{\prime} \gamma_{4}+\epsilon_{j},
$$

where $S_{i-f}^{U S, j}$ is the share of intrafirm imports in total U. S. imports from country $j, K^{j} / L^{j}$ is the capital-labor ratio of country $j, L^{j}$ is population in country $j, W_{j}$ is a vector of controls, and $\epsilon_{j}$ is an orthogonal error term. The theory predicts that $\gamma_{2}$ should be positive. In fact, from the log-linearization, we can derive a much more precise prediction; i.e., $\gamma_{2}=\left(1-\sigma_{L}\right) \sigma_{L} /\left(1-\sigma_{L}-\widetilde{\beta_{Z}}\right)$. This implies that the elasticity of the share of intrafirm imports to the capital-labor ratio should not be lower than the labor share in the economy. Furthermore, from the last statement in Proposition 2 , we should not expect $\gamma_{3}$ to be significantly different from zero.

The third test I conduct consists of running a regression analogous to (24) but with the log of total intrafirm imports (instead of its share in total imports) on the left-hand side. In particular, I consider the specification,

$$
\ln \left(M_{i-f}^{U S, j}\right)=\omega_{1}+\omega_{2} \ln \left(K^{j} / L^{j}\right)+\omega_{3} \ln \left(L^{j}\right)+W_{j}^{\prime} \omega_{4}+\epsilon_{j} .
$$

In view of Lemma 1 , both $\omega_{2}$ and $\omega_{3}$ should be positive. Furthermore, it is easy to show that the model imposes the restrictions $\omega_{2}>\gamma_{2}$ and $\omega_{3}=1 .{ }^{30}$ In words, the total volume of intrafirm imports should be more responsive to the capital-labor ratio of the exporting country than its share in total imports, while its elasticity with respect to the size of the exporting country should be one.

\section{IV.B. Data}

The left-hand-side variables are constructed combining data on intrafirm U. S. imports and overall U. S. imports. Intrafirm U. S. imports include (i) imports shipped by overseas affiliates to their U. S. parents, and (ii) imports shipped to U. S. affiliates by their foreign parent group. The series were obtained from the direct investment data set available from the Bureau of Economic Analysis (BEA) website. For reasons discussed in Appendix 3, I am restricted to running equation (23) for a panel consisting of 23 manufacturing industries and four years of data: 1987, 1989, 1992, and 1994. As for equations (24) and (25), data availability limits the analysis to a cross section of 28 countries in 1992 (see

30. A log-linear approximation of equation (21) around $K^{j} / L^{j}=K / L$ yields $\omega_{2}=\left(1-\sigma_{L}\right)\left(1-\widetilde{\beta_{Z}}\right) /\left(1-\sigma_{L}-\widetilde{\beta_{Z}}\right)>\gamma_{2}$ and $\omega_{3}=1$. See Antràs [2003] for details. 
TABLE II

Share of Intrafirm Imports in Total U. S. Imports (Percent)

\begin{tabular}{lclrllll}
\hline \hline \multicolumn{3}{c}{ by Industry (avg. 1987-1994) } & \multicolumn{4}{c}{ by Country (1992) } \\
\hline DRU & 65.5 & FOO & 13.9 & CHE & 64.1 & ESP & 15.5 \\
OCH & 40.9 & PAP & 12.7 & SGP & 55.4 & AUS & 15.5 \\
VEH & 39.8 & FME & 12.6 & IRL & 53.7 & JPN & 14.2 \\
ELE & 37.3 & STO & 11.8 & CAN & 45.1 & ISR & 12.4 \\
COM & 36.7 & INS & 11.1 & NDL & 42.2 & HKG & 11.2 \\
CHE & 35.9 & TRA & 10.7 & MEX & 41.7 & PHL & 8.4 \\
CLE & 35.7 & PLA & 9.1 & PAN & 35.8 & ITA & 8.1 \\
RUB & 23.9 & PRI & 6.1 & GBR & 33.2 & ARG & 5.1 \\
AUD & 23.8 & LUM & 4.1 & DEU & 31.9 & COL & 4.6 \\
OEL & 18.9 & OMA & 2.6 & MYS & 30.1 & OAN & 4.6 \\
IMA & 17.3 & TEX & 2.3 & BEL & 27.3 & VEN & 1.4 \\
BEV & 15.1 & & & BRA & 25.9 & CHL & 1.3 \\
& & & & FRA & 21.6 & IDN & 1.3 \\
& & & & SWE & 16.8 & EGY & 0.1 \\
\hline \hline
\end{tabular}

See Appendixes 4 and 5 for a list of industries and countries.

Appendixes 4 and 5 for a complete list of industries and countries). In the panel of industries the share of intrafirm imports in total U. S. imports ranges from a value slightly below 1 percent for textiles in 1987 to around 82 percent for drugs in 1994, for an overall average of 21.2 percent. In the cross section of countries the share ranges from an almost negligible 0.1 percent for Egypt up to 64.1 percent for Switzerland, for an overall average of 22.4 percent (see Table II).

Most right-hand-side variables in the cross-industry regressions are taken from the NBER Manufacturing Industry Productivity Database. ${ }^{31}$ Capital intensity is measured as the ratio of the total capital stock to total employment in the corresponding exporting industry. ${ }^{32}$ To control for other potential determinants of internalization, I run equation (23) including other industry characteristics one at a time. First, I allow for the possibility that the integration decision might be determined by the human-

31. The SIC classification used in the NBER Manufacturing Database was converted to BEA industry categories using a concordance table available from the BEA and is reproduced in Appendix 4.

32. This presupposes that U. S. industry capital intensities are similar to those in the rest of the world. In a world with factor price equalization, this would naturally be the case. In a more general setup, the much weaker assumption of no factor intensity reversals is sufficient to ensure that the same qualitative results would be obtained by using factor intensity data from the exporting country. 
capital intensity of the production process. To the extent that final-good producers also contribute to their suppliers' costs related to the acquisition of human capital (e.g., by financing training programs), a model along the lines of the one developed above would indeed predict an effect of human-capital intensity. I measure human-capital intensity as the ratio of nonproduction workers to production workers in a given industry, as reported in the NBER Manufacturing data set. A similar argument could be used to defend the inclusion of some measure of the importance of $R \& D$ and advertising in the production process. $R \& D$ intensity and advertising intensity are defined, respectively, as the ratio of $R \& D$ expenditures to sales and advertising expenditures to sales, and are obtained from a 1977 FTC survey. ${ }^{33}$ I also control for the possibility that the integration decision may be driven by the size of scale economies at the plant level, as measured by average capital stock per establishment. ${ }^{34}$ Finally, the decision to integrate could also be related to the importance of suppliers' production in the overall value chain. A rough way of proxying for this is to control for the share of value added in total industry sales, again from the NBER manufacturing data set.

The main right-hand-side variables in equations (24) and (25), including the capital-labor ratio of the exporting country and its total population, are taken from the cross section of country variables for the year 1988 constructed by Hall and Jones [1999]. In the present paper I have adopted the view that capital abundance is a crucial determinant of the amount of multinational activity in a given country. Zhang and Markusen [2001] develop a model in which the volume of foreign direct investment in a given country is instead crucially affected by its skilled-labor abundance. To control for these possible effects, I include the measure of human capital abundance reported in Hall and Jones [1999]. Other authors have stressed the importance of fiscal and institutional factors in determining the attractiveness of foreign direct investment in a given country. Countries with relatively lower corporate taxes and relatively better institutional environments should, in principle, be more prone to hosting affiliates of U. S. firms. In the regressions below, I use data on average

33. This measure has been widely used in the literature (e.g., Cohen and Klepper [1992], and Brainard [1997]).

34. This variable was constructed combining the capital stock figures from the NBER data set with data on the number of establishments published by the U. S. Census Bureau in its County Business Patterns series. 
corporate tax rates from a Price Waterhouse survey, as well as the index of institutional quality for the year 1990 reported in Gwartney et al. [2002]. Within the institutional factors, I also attempt to distinguish between the effect of a country's degree of openness to FDI and that of its degree of openness to international trade. Indices of openness to FDI and to trade are obtained from survey data reported in the World Competitiveness Report [1992]. Table III reports descriptive statistics for all variables included in the regressions.

\section{IV.C. Results}

The top panel of Table IV presents random effects estimates of equation (23). Column I includes no controls in the regression and is therefore the econometric analog to Figure I. The coefficient on $\ln (K / L)_{m}$ is positive and significantly different from zero at the 1 percent significance level. The estimated elasticity of the share of intrafirm imports with respect to the capital-labor ratio in production implies that a 1 percent increase in $K / L$ increases the share of intrafirm imports by around 0.95 percent. Column II includes human-capital intensity in the regression. This leads to a reduction of the estimate of $\theta_{2}$ which, however, remains highly significant. The coefficient on $\ln (H / L)_{m}$ is positive but not sta-

TABLE III

DESCRIPTIVE StATISTICS

\begin{tabular}{|c|c|c|c|c|c|}
\hline & Obs & Mean & St. dev. & Min & Max \\
\hline $\ln \left(S_{i-f}^{U S, R O W}\right)_{m}$ & 92 & -1.90 & 0.92 & -4.74 & -0.19 \\
\hline $\ln (K / L)_{m}$ & 92 & 4.26 & 0.57 & 3.21 & 5.73 \\
\hline $\ln (H / L)_{m}$ & 92 & -0.69 & 0.60 & -1.78 & 0.60 \\
\hline $\ln (R \& D / \text { Sales })_{m}$ & 92 & -4.20 & 1.00 & -6.07 & -2.47 \\
\hline $\ln (\text { ADV/Sales })_{m}$ & 92 & -4.27 & 1.10 & -6.63 & -2.24 \\
\hline $\ln (\text { Scale })_{m}$ & 92 & 1.63 & 0.92 & 0.06 & 3.48 \\
\hline $\ln (\text { VAD/Sales })_{m}$ & 92 & -0.66 & 0.18 & -1.13 & -0.32 \\
\hline $\ln \left(S_{i-f}^{U S, j}\right)$ & 28 & -2.08 & 1.44 & -6.67 & -0.45 \\
\hline $\ln (K / L)_{j}$ & 28 & 10.54 & 0.86 & 8.13 & 11.59 \\
\hline $\ln (L)_{j}$ & 28 & 16.03 & 1.20 & 13.63 & 18.16 \\
\hline $\ln (H / L)_{j}$ & 28 & 0.82 & 0.19 & 0.47 & 1.10 \\
\hline $\operatorname{CorpTax}_{j}$ & 28 & 0.32 & 0.08 & 0.15 & 0.44 \\
\hline EconFreedom $_{j}$ & 28 & 6.36 & 1.22 & 4.19 & 8.24 \\
\hline$O p F D I$ & 26 & 7.83 & 1.23 & 4.73 & 9.57 \\
\hline OpTrade & 26 & 6.70 & 1.22 & 3.52 & 8.67 \\
\hline $\ln \left(M_{i-f}^{U S_{, j}}\right)$ & 28 & 6.36 & 2.64 & -1.39 & 10.49 \\
\hline
\end{tabular}


TABLE IV

FACTOR INTENSITY AND THE SHARE $S_{i-f}^{U S, R O W}$

\begin{tabular}{|c|c|c|c|c|c|c|}
\hline \multirow{2}{*}{$\begin{array}{l}\text { Dep. var. is } \\
\ln \left(S_{i-f}^{U S, R O W}\right)_{m}\end{array}$} & \multicolumn{6}{|c|}{ Random effects regressions } \\
\hline & $\mathrm{I}$ & II & III & IV & $\mathrm{V}$ & VI \\
\hline $\ln (K / L)_{m}$ & $\begin{array}{l}0.947 \text { *** } \\
(0.187)\end{array}$ & $\begin{array}{l}0.861^{* * * *} \\
(0.190)\end{array}$ & $\begin{array}{l}0.780 * * * \\
(0.160)\end{array}$ & $\begin{array}{l}0.776^{* * * *} \\
(0.162)\end{array}$ & $\begin{array}{l}0.703^{* * * *} \\
(0.249)\end{array}$ & $\begin{array}{l}0.723 \text { *** } \\
(0.253)\end{array}$ \\
\hline $\ln (H / L)_{m}$ & & $\begin{array}{c}0.369 \\
(0.213)\end{array}$ & $\begin{array}{c}-0.002 \\
(0.188)\end{array}$ & $\begin{array}{c}-0.038 \\
(0.200)\end{array}$ & $\begin{array}{c}-0.037 \\
(0.206)\end{array}$ & $\begin{array}{c}-0.081 \\
(0.221)\end{array}$ \\
\hline $\ln (\text { R\&D/Sales })_{m}$ & & & $\begin{array}{l}0.451^{* * *} \\
(0.107)\end{array}$ & $\begin{array}{l}0.470^{* * * *} \\
(0.114)\end{array}$ & $\begin{array}{l}0.452 * * * \\
(0.128)\end{array}$ & $\begin{array}{l}0.421 * * * \\
(0.140)\end{array}$ \\
\hline $\ln (\text { ADVISales })_{m}$ & & & & $\begin{array}{c}0.055 \\
(0.094)\end{array}$ & $\begin{array}{c}0.059 \\
(0.097)\end{array}$ & $\begin{array}{c}0.035 \\
(0.107)\end{array}$ \\
\hline $\ln (\text { Scale })_{m}$ & & & & & $\begin{array}{c}0.068 \\
(0.179)\end{array}$ & $\begin{array}{c}0.100 \\
(0.190)\end{array}$ \\
\hline $\ln (\text { VAD/Sales })_{m}$ & & & & & & $\begin{array}{c}0.403 \\
(0.657)\end{array}$ \\
\hline$R^{2}$ & 0.50 & 0.55 & 0.72 & 0.73 & 0.73 & 0.73 \\
\hline \multirow[t]{3}{*}{ No. of obs. } & 92 & 92 & 92 & 92 & 92 & 92 \\
\hline & \multicolumn{6}{|c|}{ Fixed effects regressions } \\
\hline & $\mathrm{I}$ & II & III & IV & $\mathrm{V}$ & VI \\
\hline $\ln (K / L)_{m}$ & $\begin{array}{l}0.599 * * \\
(0.299)\end{array}$ & $\begin{array}{l}0.610^{* *} \\
(0.300)\end{array}$ & $\begin{array}{l}0.610 * * \\
(0.300)\end{array}$ & $\begin{array}{l}0.610^{* *} \\
(0.300)\end{array}$ & $\begin{array}{l}0.943 * * \\
(0.412)\end{array}$ & $\begin{array}{l}1.058 * * \\
(0.410)\end{array}$ \\
\hline $\begin{array}{l}p \text {-value } \\
\text { Wu-Hausman } \\
\text { test }\end{array}$ & 0.14 & 0.27 & 0.62 & 0.64 & 0.52 & 0.19 \\
\hline
\end{tabular}

Standard errors in parentheses $\left(*, * *\right.$, and, $\left.{ }^{* * *}\right)$ are 10,5 , and 1 percent significance levels.

tistically significant. In column III the ratio of R\&D expenditures to sales is also included in the regression and is found to have a very significant effect on the share of intrafirm imports. The estimate of $\theta_{2}$ in column III is lower than that implied by Figure I, but it still implies that a 1 percent increase in $K / L$, should lead to a 0.78 percent increase in the share of intrafirm imports. The inclusions of advertising intensity in column IV, of the size of economies of scale in column $\mathrm{V}$, and of value-added intensity in column VI, do not overturn any of the qualitative results. None of these variables seems to affect significantly the share of intrafirm imports, while capital intensity and R\&D intensity remain significant at the 1 percent level.

Consistency of the random effects estimates requires the industry effects to be uncorrelated with the other explanatory variables. One might worry that the omission of some relevant industry variables might lead to biases in the random effects 
TABLE V

FACTOR ENDOWmENTS AND THE SHARE $S_{i-f}^{U S, j}$

\begin{tabular}{|c|c|c|c|c|c|c|}
\hline $\begin{array}{l}\text { Dep. var. is } \\
\ln \left(S_{i-f}^{U S, j}\right)\end{array}$ & I & II & III & IV & $\mathrm{V}$ & VI \\
\hline $\ln (K / L)_{j}$ & $\begin{array}{l}1.141 * * * \\
(0.289)\end{array}$ & $\begin{array}{l}1.110^{* * * *} \\
(0.299)\end{array}$ & $\begin{array}{l}1.244^{* * * *} \\
(0.427)\end{array}$ & $\begin{array}{l}1.239^{* * * *} \\
(0.415)\end{array}$ & $\begin{array}{l}1.097 * * \\
(0.501)\end{array}$ & $\begin{array}{l}1.119^{* * *} \\
(0.399)\end{array}$ \\
\hline $\ln (L)_{j}$ & & $\begin{array}{c}-0.133 \\
(0.168)\end{array}$ & $\begin{array}{c}-0.159 \\
(0.164)\end{array}$ & $\begin{array}{c}-0.158 \\
(0.167)\end{array}$ & $\begin{array}{c}-0.142 \\
(0.170)\end{array}$ & $\begin{array}{c}0.017 \\
(0.220)\end{array}$ \\
\hline $\ln (H / L)_{j}$ & & & $\begin{array}{c}-1.024 \\
(1.647)\end{array}$ & $\begin{array}{c}-0.890 \\
(1.491)\end{array}$ & $\begin{array}{c}-1.273 \\
(1.367)\end{array}$ & $\begin{array}{c}-0.822 \\
(1.389)\end{array}$ \\
\hline $\operatorname{CorpTax}_{j}$ & & & & $\begin{array}{c}-0.601 \\
(3.158)\end{array}$ & $\begin{array}{c}0.068 \\
(3.823)\end{array}$ & $\begin{array}{c}1.856 \\
(2.932)\end{array}$ \\
\hline EconFreedom $_{j}$ & & & & & $\begin{array}{c}0.214 \\
(0.213)\end{array}$ & \\
\hline$O p F D I_{j}$ & & & & & & $\begin{array}{c}-0.384^{*} \\
(0.218)\end{array}$ \\
\hline OpTrade $_{j}$ & & & & & & $\begin{array}{c}0.292 \\
(0.273)\end{array}$ \\
\hline$R^{2}$ & 0.46 & 0.47 & 0.48 & 0.50 & 0.50 & 0.43 \\
\hline No. of obs. & 28 & 28 & 28 & 28 & 28 & 26 \\
\hline
\end{tabular}

Robust standard errors in parentheses (*, **, and, ***) are 10, 5, and 1 percent significance levels.

estimates. As a robustness check, the bottom panel of Table IV reports the fixed effects estimates of $\theta_{2}$ together with the $p$-value of a Wu-Hausman test for exogeneity of the industry effects. ${ }^{35}$ The fixed effects estimates of $\theta_{2}$ are all significantly different from zero at the 5 percent significance level. Furthermore, the point estimates are not too different from their random effects counterparts, and the null hypothesis of exogeneity of the industry effects cannot be rejected at reasonable significance levels.

Table V reports OLS estimates of equation (24) for the cross section of 28 countries. The estimates in column I correspond to the simple correlation depicted in Figure II. The elasticity of the share of intrafirm imports with respect to the capital-labor ratio of the exporting country is significantly different from zero, and as predicted by the theory, the point estimate of the elasticity is necessarily higher than any plausible labor share in the world. Column II confirms the claim in Proposition 2 that, for a given $K^{j} / L^{j}$, the size of the exporting country should not affect the share $S_{i-f}^{U S, j}$. The coefficient of $\ln (L)_{j}$ is actually negative but statisti-

35. The R\&D and advertising intensity variables are purely cross-sectional and are thus dropped in the estimation. This explains that the estimates in columns II, III, and IV are all identical. 
cally indistinguishable from zero. Column III introduces the measure of human-capital abundance in the regression. Contrary to what might have been expected (cf. Zhang and Markusen [2001]), the estimated coefficient on $\ln (H / L)_{j}$ is negative, although again insignificantly different from zero. Conversely, the effect of physical-capital abundance remains significantly positive at the 1 percent level. As shown in column IV and V, controlling for the average corporate tax rate and the index of institutional quality does not overturn the results. The coefficients on both $\operatorname{CorpTax}_{j}$

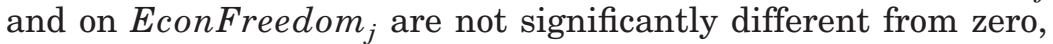
while the estimate of $\gamma_{2}$ remains significantly positive at the 5 percent level. Finally, column VI suggests that the insignificance of the institutional variable in column $\mathrm{V}$ might be due to the counterbalancing effects of different policies. In particular, the share of intrafirm trade is negatively affected by the degree of openness to FDI but positively (although insignificantly) affected by the degree of openness to trade. ${ }^{36}$ Overall, the significant effect of the capital-labor ratio of the exporting country on the share of intrafirm imports appears to be very robust.

Table VI presents the OLS estimates of equation (25). Columns I and II confirm that the theoretical predictions in Lemma 1 are borne out by the data. Both the capital-labor ratio of the exporting country and its size seem to have a significant positive effect on the volume of U. S. intrafirm imports. Consistently with the theory, the elasticity of $M_{i-f}^{U S, j}$ with respect to $K^{j} / L^{j}$ is estimated to be higher than the elasticity of $S_{i-f}^{U S, j}$ with respect to $K^{j} / L^{j}$. Furthermore, the elasticity of $M_{i-f}^{U S, j}$ with respect to $L^{j}$ is, as predicted, not significantly different from one. As reported in columns III and IV, controlling for human capital abundance and for the average corporate tax rate has a negligible effect on the coefficients. The inclusion of the institutional index in column $\mathrm{V}$ leads to a substantial fall in the estimated elasticity of intrafirm imports to the capital-labor ratio, but the effect remains significant at the 5 percent level. Finally, column VI includes separate measures of openness to FDI and openness to trade. The results indicate that controlling for the capital-labor ratio of the exporting country, intrafirm imports are negatively affected by its open-

36. Including $O p F D I$ and $O p T r a d e$ reduces the number of observation to 26 , since no data on these variables are available for Egypt and Panama. I reran the regressions in columns I through $\mathrm{V}$, without these two countries and obtained very similar results. 
TABLE VI

Factor Endowments And the Volume $M_{i-f}^{U S, j}$

\begin{tabular}{|c|c|c|c|c|c|c|}
\hline $\begin{array}{l}\text { Dep. var. is } \\
\ln \left(M_{i-f}^{U S, j}\right)\end{array}$ & I & II & III & IV & V & VI \\
\hline $\ln (K / L)_{j}$ & $\begin{array}{l}2.048 * * * \\
(0.480)\end{array}$ & $\begin{array}{l}2.192 * * * \\
(0.458)\end{array}$ & $\begin{array}{l}2.188^{* * * *} \\
(0.716)\end{array}$ & $\begin{array}{l}2.154 * * * \\
(0.663)\end{array}$ & $\begin{array}{l}1.650^{* * *} \\
(0.762)\end{array}$ & $\begin{array}{l}2.096 \text { **** } \\
(0.695)\end{array}$ \\
\hline $\ln (L)_{j}$ & & $\begin{array}{l}0.607^{* *} \\
(0.229)\end{array}$ & $\begin{array}{l}0.608^{* *} \\
(0.268)\end{array}$ & $\begin{array}{l}0.614^{* *} \\
(0.271)\end{array}$ & $\begin{array}{l}0.670 * * \\
(0.243)\end{array}$ & $\begin{array}{c}0.700 \\
(0.419)\end{array}$ \\
\hline $\ln (H / L)_{j}$ & & & $\begin{array}{c}0.031 \\
(3.289)\end{array}$ & $\begin{array}{c}0.953 \\
(3.316)\end{array}$ & $\begin{array}{c}-0.406 \\
(2.992)\end{array}$ & $\begin{array}{c}0.708 \\
(3.052)\end{array}$ \\
\hline $\operatorname{CorpTax}_{j}$ & & & & $\begin{array}{c}-4.135 \\
(5.294)\end{array}$ & $\begin{array}{c}-1.763 \\
(5.955)\end{array}$ & $\begin{array}{c}-0.647 \\
(5.295)\end{array}$ \\
\hline EconFreedom $_{j}$ & & & & & $\begin{array}{c}0.795 \\
(0.443)\end{array}$ & \\
\hline$O p F D I_{j}$ & & & & & & $\begin{array}{c}-1.006^{* *} \\
(0.474)\end{array}$ \\
\hline OpTrade $_{j}$ & & & & & & $\begin{array}{c}0.674 \\
(0.560)\end{array}$ \\
\hline$R^{2}$ & 0.44 & 0.52 & 0.52 & 0.53 & 0.60 & 0.49 \\
\hline No. of obs. & 28 & 28 & 28 & 28 & 28 & 26 \\
\hline
\end{tabular}

Robust standard errors in parentheses $(*, * *$, and, ***) are 10,5 , and 1 percent significance levels.

ness to FDI. ${ }^{37}$ More importantly, the effect of the capital-labor ratio continues to be significant at the 1 percent level, while the effect of size is only marginally insignificant at the 10 percent level.

\section{Conclusions}

This paper began by unveiling two systematic patterns in the intrafirm component of international trade. Traditional trade theory is silent on the boundaries of firms. Existing contributions to the theory of the firm tend to be partial-equilibrium in scope and have ignored the international dimensions of certain intrafirm transactions. Building on two workhorse models in international trade and the theory of the firm, I have developed a simple model that can account for the novel facts identified in the introduction. By combining a Grossman-Hart-Moore view of the

37. This may seem puzzling, but the model can shed light on this finding. Recall from footnote 18 that the attractiveness of integration is decreasing in the share $\phi$ of ex post surplus accruing to final-good producers. If a higher openness to FDI corresponds to a larger bargaining power for foreign final-good producers, then on this account the model is consistent with the coefficient on OpFDI being significantly negative. 
firm with a Helpman-Krugman view of international trade, I have constructed a model that determines both the pattern of international trade and the boundaries of firms in a unified framework.

Nevertheless, much remains to be done. Future empirical investigations are likely to unveil new distinct features of the volume of intrafirm trade that cannot be accounted for by the simple model developed here. On the one hand, the GrossmanHart-Moore theory enhances our understanding of only a subset of the determinants of ownership structure. Holmström and Milgrom [1994] have emphasized that, in many situations, issues related to job design and the cost of measuring performance are more relevant when choosing between inside or outside procurement. It would be interesting to investigate the implications of such a view of the firm for the volume of intrafirm trade. On the other hand, in determining trade patterns, I have resorted to a very simple trade model. Future work should help us to understand potential channels by which technological differences, transport costs, or international factor-price differences can affect the organization and location of international production.

\section{Appendix 1: The Rationale for Cost Sharing}

In Appendix 1, I show that Assumption 1 is sufficient to ensure that final-good producers always choose to contribute to their suppliers' capital expenditures.

Consider the problem faced by an independent supplier when the final-good producer decides not to contribute to variable costs. In such a case, the supplier chooses $K_{x, Y}(i)$ and $L_{x, Y}(i)$ to maximize $(1-\phi) R_{Y}(i)-r K_{x, Y}(i)-w L_{x, Y}(i)$, and the final-good producer simply receives $\phi R_{Y}(i)$ ex post. Following similar steps as in the main text, it is easy to show that ex ante profits for a final-good producer can now be expressed as

$$
\tilde{\pi}_{F, Y, O}=(\phi+(1-\alpha)(1-\phi)) A_{Y}\left(\frac{r^{\beta Y} w^{1-\beta Y}}{\alpha(1-\phi)}\right)^{-\alpha /(1-\alpha)}-f r^{\beta Y} w^{1-\beta_{Y}}
$$

The case of an integrated supplier is completely analogous. In particular, the same expression (26) applies with $\bar{\phi}$ replacing $\phi$. Comparing equation (26) with (6) and (7), one can show the following. 
Lemma 2. Under Assumption 1 (i.e., if $\phi>1 / 2$ ) final-good producers will always decide to bear the cost of renting the capital required to produce the intermediate input.

Proof. Combining equations (7) and (26), it follows that regardless of the level of demand $A_{Y}$ the final-good producer in a pair of stand-alone firms will decide to incur the capital expenditures itself whenever

$$
\begin{aligned}
\left(1-\alpha\left(1-\beta_{Y}\right)+\alpha \phi\left(1-2 \beta_{Y}\right)\right)\left(\frac{\phi}{1-\phi}\right)^{\alpha \beta /(1-\alpha)} & \\
& >\phi+(1-\alpha)(1-\phi),
\end{aligned}
$$

which holds whenever $\phi>1 / 2$. To see this, define the function

$$
\begin{aligned}
H(\phi)=(1-\alpha(1-\beta)+\alpha \phi(1-2 \beta)) & \left(\frac{\phi}{1-\phi}\right)^{\alpha \beta \gamma /(1-\alpha)} \\
& -\phi-(1-\alpha)(1-\phi),
\end{aligned}
$$

and notice first that $H(1 / 2)=0$. Next note that

$$
\begin{aligned}
H^{\prime}(\phi)=\alpha\left(\left(\frac{\phi}{1-\phi}\right)^{\alpha \beta /(1-\alpha)}\right. & -1)+\alpha \beta\left(\frac{\phi}{1-\phi}\right)^{\alpha \beta /(1-\alpha)} \\
& \times\left(\frac{1-\alpha(1-\beta)+\alpha \phi(1-2 \beta)}{(1-\alpha)(1-\phi) \phi}-2\right) .
\end{aligned}
$$

The first term is clearly positive when $\phi>1 / 2$. Furthermore, since $[(1-\alpha(1-\beta)+\alpha \phi(1-2 \beta))] /[(1-\alpha)(1-\phi) \phi]$ increases with $\alpha$, it follows that $[(1-\alpha(1-\beta)+\alpha \phi(1-2 \beta))] /[(1-\alpha)(1-\phi) \phi]-$ $2 \geq 1 /((1-\phi) \phi)-2>0$ and the second term is also positive. Hence, $H(\phi)>0$ for all $\phi>1 / 2$. Since $\bar{\phi}>\phi$, as long as $\phi>1 / 2$, final-good producers in integrated pairs will also decide to rent the capital stock and hand it to the supplier.

QED

The intuition for this result is that the higher is $\phi$, the smaller is the fraction of the marginal return to its ex ante investments that the supplier receives, and thus the less it will invest in $K_{x, Y}$. This underinvestment will have a negative effect on the value of the relationship, which is what the final-good producer maximizes ex ante. For a large enough $\phi$ (in this case $1 / 2$ ), the detrimental effect of the underinvestment in capital is large enough so as to make it worthwhile for the final-good producer to bear the cost of renting $K_{x, Y}$ itself, even if by doing so 
it now exposes itself to a holdup by the supplier. In other words, for $\phi>1 / 2$, a supplier incurring all variable costs faces a too severe holdup problem, which the final-good producer finds optimal to alleviate by sharing part of the required ex ante investments.

\section{Appendix 2: Proof of Proposition 1}

The first step of the proof consists in showing that $\Theta^{\prime}\left(\beta_{k}\right)>$ 0 for all $\beta_{k} \in[0,1]$.

Lemma 3. The attractiveness of integration, as measured by $\Theta\left(\beta_{k}\right)$, increases with the capital intensity of intermediate input production $\beta_{k}: \Theta^{\prime}\left(\beta_{k}\right)>0$ for all $\beta_{k} \in[0,1]$.

Proof. From simple differentiation of (8), it follows that $\Theta^{\prime}\left(\beta_{k}\right)>0$ if and only if

$$
\Omega\left(\beta_{k}\right) \ln \left(1+\frac{\delta^{\alpha}}{\phi\left(1-\delta^{\alpha}\right)}\right)>(2-\alpha)(1-\alpha)(1-\phi) \delta^{\alpha},
$$

where $\Omega\left(\beta_{k}\right)=\left(1-\alpha(1-\bar{\phi})+\alpha \beta_{k}(1-2 \bar{\phi})\right)(1-\alpha(1-\phi)+$ $\left.\alpha \beta_{k}(1-2 \phi)\right)$ and remember that $\bar{\phi}=\delta^{\alpha}+\phi\left(1-\delta^{\alpha}\right)$. Now notice that if $\bar{\phi}>\phi \geq 1 / 2$ then $\Omega^{\prime}\left(\beta_{k}\right)<0 \forall \beta_{k} \in[0,1]$, and if $\phi<\bar{\phi} \leq$ $1 / 2$, then $\Omega^{\prime}\left(\beta_{k}\right)>0 \forall \beta_{k} \in[0,1]$. Furthermore, if $\bar{\phi}>1 / 2>\phi$, then $\Omega^{\prime \prime}\left(\beta_{k}\right)<0 \forall \beta_{k} \in[0,1]$. It thus follows that $\Omega\left(\beta_{k}\right) \geq \min$ $\{\Omega(0), \Omega(1)\}$. Without loss of generality, assume that $\Omega(1)=(1-$ $\alpha \phi)\left(1-\alpha\left(\phi+(1-\phi) \delta^{\alpha}\right)<\Omega(0)\right.$ (the case $\Omega(1)>\Omega(0)$ is entirely symmetric). We need to show that $\vartheta(\delta)>0$ for all $\delta \in(0,1)$ where

$$
\vartheta(\delta)=\ln \left(1+\frac{\delta^{\alpha}}{\phi\left(1-\delta^{\alpha}\right)}\right)-\frac{(2-\alpha)(1-\alpha)(1-\phi) \delta^{\alpha}}{(1-\alpha \phi)\left(1-\alpha\left(\phi+(1-\phi) \delta^{\alpha}\right)\right.} .
$$

From simple differentiation of this expression, it follows that $\vartheta^{\prime}(\delta)>0$ if and only if $(1-\alpha \rho)^{2}-(2-\alpha)(1-\alpha)(1-\rho) \rho>0$ for some $\rho \in(0,1)$. But it is simple to check that this is in fact true for all $\alpha, \rho \in(0,1)$, and therefore $\vartheta(\delta)>\vartheta(0)=0$. Notice that Assumption 1 is not necessary for this result.

QED

Next, notice that from equation (8) and the definition of $\bar{\phi}$, we can write 


$$
\begin{aligned}
& \Theta(0)=\frac{1-\alpha(1-\bar{\phi})}{1-\alpha(1-\phi)}\left(\frac{1-\bar{\phi}}{1-\phi}\right)^{\alpha /(1-\alpha)}<1 \\
& \text { and } \Theta(1)=\frac{1-\alpha \bar{\phi}}{1-\alpha \phi}\left(\frac{\bar{\phi}}{\phi}\right)^{\alpha /(1-\alpha)}>1 .
\end{aligned}
$$

The inequalities follow from $\bar{\phi}>\phi$ and the fact that $(1-\alpha x)$ $x^{\alpha /(1-\alpha)}$ is an increasing function of $x$ for $\alpha \in(0,1)$ and $x \in(0,1)$. Given Lemma 3 , it thus follows that there exists a unique $\hat{\beta} \in(0,1)$ such that $\Theta\left(\beta_{k}\right)<1$ for $\beta_{k}<\hat{\beta}, \Theta\left(\beta_{k}\right)>1$ for $\beta_{k}>\hat{\beta}$, and $\Theta\left(\beta_{k}\right)=1$ for $\beta_{k}=\hat{\beta}$.

QED

\section{ApPENDIX 3: DATA}

Appendix 3 discusses in more detail the construction of the share of intrafirm imports in total U. S. imports. Intrafirm imports were obtained from the "Financial and Operating Data" on multinational firms downloadable from the BEA website. Since in the model ownership is associated with control, I restricted the sample to majority-owned affiliates. As discussed in the main text, the BEA suppresses data cells in order to avoid disclosure of individual firm data. The unsuppressed data are only available to researchers affiliated with the BEA. Unfortunately, one of the requirements for affiliation is being a U. S. citizen (which I am not).

To construct intrafirm imports by industry, I combine data from foreign affiliates of U. S. firms and U. S. affiliates of foreign firms. Intrafirm imports comprise (i) imports shipped by overseas affiliates to their U. S. parents, by industry of affiliate; and (ii) imports shipped to U. S. affiliates by their foreign parent group, by industry of affiliate. ${ }^{38}$ The sum of these two elements was constructed at the finest level of disaggregation available, focusing on manufacturing industries and excluding natural-resource

38. The BEA defines a foreign parent group as consisting of (1) the foreign parent, (2) any foreign person, proceeding up the foreign parent's ownership chain, that owns more than 50 percent of the person below it, up to and including the ultimate beneficial owner, and (3) any foreign person, proceeding down the ownership chain(s) of each of these members, that is owned more than 50 percent by the person above it.

The conceptually correct disaggregation for case (ii) would have been by the industry of the exporter (i.e., of the foreign parent group). Unfortunately, these series are not available. Intrafirm imports of type (i), however, constitute more than two-thirds of all intrafirm imports. More importantly, a pattern similar to that in Figure I emerges when the analysis is restricted to intrafirm imports of type (i). 
industries (in particular, petroleum, ferrous metals, and nonferrous metals). ${ }^{39} \mathrm{I}$ also restricted the sample to years in which benchmark surveys were conducted. Overall, I end up with 23 industries and four years: 1987, 1989, 1992, and 1994.

To construct intrafirm imports by country, I add up (i) imports shipped by overseas affiliates to their U. S. parents, by country of origin, and (ii) imports shipped to U. S. affiliates by their foreign parent group, by country of origin. In both cases I restrict the analysis to manufacturing industries, although in this case it was impossible to remove those transactions involving natural resources (this might explain why intrafirm imports from Chile and Venezuela are lower than predicted in Figure II). The BEA performs two types of manipulations to the data. Apart from suppressing cells to avoid disclosure of data of individual companies, it also assigns a unique symbol to trade flows below $\$ 500,000$. I assign a value of $\$ 250,000$ to these cells. ${ }^{40}$ Overall, I end up with a single cross section with 28 countries in 1992. All the other benchmark survey years lack at least one of the components of intrafirm imports.

Finally, in order to compute the share of intrafirm imports, I construct total U. S. imports by industry and year, and then by country of origin, using data put together by Robert Feenstra and available from the NBER website. Import figures correspond to their c.i.f. values. Feenstra's four-digit industry classification was matched to the 23 BEA industries using a conversion table available from BEA and reproduced in Appendix 4.

As pointed out by a referee, a significant portion of intrafirm trade involves final goods that are shipped from a manufacturing plant to an overseas wholesale affiliate which then distributes the good in the foreign country. Unfortunately, the BEA data set does not distinguish between imports of intermediate inputs and imports of final goods, so that the latter cannot be subtracted from intrafirm imports. As pointed out by the same referee, however, this is not necessarily a problem for the empirical work as an analogous theoretical model can also be interpreted in the context of a supplier-distributor relationship.

39. Patterns of ownership in natural-resource sectors are likely to be determined by factors such as national sovereignty, from which I abstract in the model.

40. This is only done for two observations. The results are robust to imputing alternative values between 0 and $\$ 500,000$. 
ApPendix 4: Industry Description and Classification

\begin{tabular}{lll}
\hline \hline Code & \multicolumn{1}{c}{ Description } & \multicolumn{1}{c}{$\begin{array}{c}\text { Corresponding industry } \\
\text { SIC classification }\end{array}$} \\
\hline BEV & Beverages & 208 \\
FOO & Other food and kindred products & $201-207,209$ \\
CHE & Industrial chemicals and synthetics & $281,282,286$ \\
DRU & Drugs & 283 \\
CLE & Soap, cleaners and toilet goods & 284 \\
OCH & Other chemical products & $285,287,289$ \\
FME & Fabricated metal products & $341-349$ \\
COM & Computer and office equipment & 357 \\
IMA & Other industrial machinery and & $351-356,358,359$ \\
& $\quad$ equipment & \\
AUD & Audio, video, and communications & 365,366 \\
& $\quad$ equipment & 367 \\
ELE & Electronic components and accessories & $361-364,369$ \\
OEL & Other electronic and electrical & \\
& machinery & $221-229,231-39$ \\
TEX & Textile products and apparel & $241-49,251-59$ \\
LUM & Lumber, wood, furniture, and fixtures & $261-263,265,267$ \\
PAP & Paper and allied products & $271-279$ \\
PRI & Printing and publishing & $301,302,305,306$ \\
RUB & Rubber products & 308 \\
PLA & Miscellaneous plastics products & $321-29$ \\
STO & Stone, clay, and glass products & 371 \\
VEH & Motor vehicles and equipment & $372-376,379$ \\
TRA & Other transportation equipment & $381,382,384-387$ \\
INS & Instruments and related products & $211-19,311-19,391-99$ \\
OMA & Other manufacturing & \\
\hline \hline & &
\end{tabular}

APPEndix 5: COUNTRY CODES

\begin{tabular}{llll}
\hline \hline Code & \multicolumn{1}{c}{ Country } & Code & Country \\
\hline ARG & Argentina & IDN & Indonesia \\
AUS & Australia & IRL & Ireland \\
BEL & Belgium & ISR & Israel \\
BRA & Brazil & ITA & Italy \\
CAN & Canada & JPN & Japan \\
CHE & Switzerland & OAN & Taiwan \\
CHL & Chile & PAN & Panama \\
COL & Colombia & PHL & Philippines \\
DEU & Germany & MEX & Mexico \\
EGY & Egypt & MYS & Malaysia \\
ESP & Spain & NDL & Netherlands \\
FRA & France & SGP & Singapore \\
GBR & United Kingdom & SWE & Sweden \\
HKG & Hong Kong & VEN & Venezuela \\
\hline \hline
\end{tabular}

HARVARD UNIVERSITY 


\section{REFERENCES}

Aghion, Philippe, Mathias Dewatripont, and Patrick Rey, "Renegotiation Design with Unverifiable Information," Econometrica, LXII (1994), 257-282.

Antràs, Pol, "Firms, Contracts, and Trade Structure," Ph.D. Thesis, Massachusetts Institute of Technology, 2003.

Aoki, Masahiko, "Toward an Economic Model of the Japanese Firm," Journal of Economic Literature, XXVIII (1990), 1-27.

Baker, P. George, and Thomas N. Hubbard, "Make or Buy in Trucking: Asset Ownership, Job Design, and Information," American Economic Review, XCIII (2003), 551-572.

Brainard, S. Lael, "An Empirical Assessment of the Proximity-Concentration Trade-off between Multinational Sales and Trade," American Economic Review, LXXXVII (1997), 520-544.

Casson, Mark, Alternatives to the Multinational Enterprise (London: Macmillan, 1979).

Caves, Richard E., Multinational Enterprise and Economic Analysis, Second Edition, (Cambridge, UK: Cambridge University Press, 1996).

Che, Yeon-Koo, and Donald B. Hausch, "Cooperative Investments and the Value of Contracting," American Economic Review, LXXXIX (1999), 125-147.

Coase, Ronald H., "The Nature of the Firm," Economica, IV (1937), 386-405.

Cohen, Wesley M., and Steven Klepper, "The Anatomy of Industry R\&D Intensity Distributions," American Economic Review, LXXXII (1992), 773-799.

Dunning, John H., Multinational Enterprises and the Global Economy, (Cambridge, UK: Addison Wesley Longman, Inc., 1993).

Ethier, Wilfred J., "The Multinational Firm," Quarterly Journal of Economics, CI (1986), 805-833.

Ethier, Wilfred J., and James R. Markusen, "Multinational Firms, Technology Diffusion and Trade," Journal of International Economics, XLI (1996), 1-28.

Grossman, Sanford J., and Oliver D. Hart, "The Costs and Benefits of Ownership: A Theory of Vertical and Lateral Integration," Journal of Political Economy, XCIV (1986), 691-719.

Grossman, Gene M., and Elhanan Helpman, "Integration versus Outsourcing in Industry Equilibrium," Quarterly Journal of Economics, CXVII (2002a), 85120.

Grossman, Gene M., and Elhanan Helpman, "Outsourcing in a Global Economy," NBER Working Paper No. 8728, 2002b.

Gwartney, James D., with Chris Edwards, Robert Lawson, Walter Park, and Veronique De Rugy, Economic Freedom of the World: 2002 Annual Report (Vancouver, Canada: Fraser Institute, 2002).

Hall, Robert E., and Charles I. Jones, "Why Do Some Countries Produce So Much More Output per Worker than Others?" Quarterly Journal of Economics, CXIV (1999), 83-116.

Hart, Oliver, Firms, Contracts, and Financial Structure (Oxford, UK: Clarendon Press, 1995).

Hart, Oliver, and John Moore, "Property Rights and the Nature of the Firm," Journal of Political Economy, XCVIII (1990), 1119-1158.

Helpman, Elhanan, "A Simple Theory of International Trade with Multinational Corporations," Journal of Political Economy, XCII (1984), 451-471.

Helpman, Elhanan, and Paul R. Krugman, Market Structure and Foreign Trade (Cambridge, MA: MIT Press, 1985).

Holmström, Bengt, and Paul Milgrom, "The Firm as an Incentive System," American Economic Review, LXXXIV (1994), 972-991.

McLaren, John, "Globalization and Vertical Structure," American Economic Review, XC (2000), 1239-1254.

Markusen, James R., "Multinationals, Multi-Plant Economies, and the Gains from Trade," Journal of International Economics, XVI (1984), 205-226.

Milgrom, Paul, and John Roberts, "Johnson Controls, Inc., Automotive Systems Group: The Georgetown, Kentucky Plant," Stanford Graduate School of Business Case S-BE-9, 1993.

Mundell, Robert A. "International Trade and Factor Mobility," American Economic Review, XLVII (1957), 321-335.

Nöldeke, Georg, and Klaus M. Schmidt, "Option Contracts and Renegotiation: A 
Solution to the Hold-up Problem," RAND Journal of Economics, XXVI (1995), $163-179$.

Romalis, John, "Factor Proportions and the Structure of Commodity Trade," mimeo Chicago Graduate School of Business, 2002.

Rugman, Alan M., Inside the Multinationals: The Economics of Internal Markets (New York: Columbia University Press, 1981).

Tirole, Jean, The Theory of Industrial Organization (Cambridge, MA: MIT Press, 1988).

UNCTAD, World Investment Report: Promoting Linkages (New York: United Nations, 2001).

Whinston, Michael D., "On the Transaction Cost Determinants of Vertical Integration," mimeo, Northwestern University, 2002.

Williamson, Oliver E., The Economic Institutions of Capitalism (New York, NY: Free Press, 1985).

World Competitiveness Report, World Economic Forum and International Institute for Management Development, 1992.

World Trade Organization, International Trade Statistics (Geneva: 2001).

Young, S., N. Hood, and J. Hamill, "Decision-Making in Foreign Owned Multinational Subsidiaries in the U. K.," ILO Working Paper No. 35, Geneva, International Labor Office, 1985.

Zeile, William J., "U. S. Intrafirm Trade in Goods," Survey of Current Business, LXXVII (1997), 23-38.

Zhang, Kevin H., and James R. Markusen, "Vertical Multinationals and HostCountry Characteristics," Journal of Development Economics, LIX (2001), 233-252. 